УДК [598.2/9:579](470.44-17)

Научная коллекция амфибий Зоологического музея Саратовского университета как основа регионального кадастра

\author{
Э. И. Кайбелева ${ }^{1}$, М. В. Ермохин ${ }^{1}$, Е. Н. Кондратьев ${ }^{1}$, \\ Е. Ю. Мосолова ${ }^{1}$, В. Г. Табачишин ${ }^{2}$, Г. В. Шляхтин ${ }^{1}$ \\ ${ }^{l}$ Саратовский национальный исследовательский государственный университет \\ имени Н. Г. Чернышевского \\ Россия, 410012, Саратов, Астраханская, 83 \\ E-mail:ecoton@rambler.ru \\ ${ }^{2}$ Саратовский филиал Института проблем экологии и эволюцчии им. А. Н. Северияова РАН \\ Россия, 410028, Саратов, Рабочая, 24 \\ E-mail: tabachishinvg@sevin.ru
}

Поступила в редакцию 24.12.2018 г., после доработки 17.05.2019 г., принята 29.05.2019 г.

\begin{abstract}
Дана характеристика и проведен анализ таксономической структуры современной батрахологической коллекции Зоологического музея Саратовского национального исследовательского государственного университета имени Н. Г. Чернышевского. В настоящее время она насчитывает 1903 экз. амфибий, относящихся к 46 видам 13 семействам. Наиболее полно в видовом отношении представлено семейство Ranidae (43.3\% от общего числа единиц хранения). В целом коллекция Ranidae содержит 711 экземпляров 10 видов лягушек, из которых на долю саратовских региональных сборов приходится 2 вида (569 экземпляра). Кроме того, относительно обширны выборки жерлянок и жаб, которые по объему составляют 18.2 и $17.9 \%$ от коллекции соответственно.

Ключевые слова: амфибии, коллекция, зоологический музей.
\end{abstract}

DOI: https://doi.org/10.18500/1814-6090-2019-19-1-2-95-124

\section{ВВЕДЕНИЕ}

Исследования по инвентаризации фауны и сохранению биологического разнообразия основываются на получении достоверной научной информации. Источником научных данных по распространению различных групп животных служат коллекционные сборы, которые хранятся в фондах зоологических и краеведческих музеев страны. Поэтому для информационного обеспечения зоологов еще в XIX в. стали публиковать каталоги зоологических коллекций, которые содержали сведения о местах хранения и сбора материалов, а некоторые даже диагнозы и описания таксонов (Кулагин, 1888; Fischer, 1822; Gunther, 1858; Cope, 1860; Muller, 1878; Boulenger, 1893, 1894, 1896; Boettger, 1898 и др.). Каталогизация музейных научных фондов делает их доступными для работы широкого круга специалистов (Щербак и др., 1997; Доценко, 2003; Писанец, 2003). В некоторых случаях сбор и хранение музейных экспонатов являются единственным способом подтверждения присутствия того или иного вида на определенной территории в разные исторические периоды (Россолимо, Павлинов, 1981). Коллекционные фонды - результат кропотливого труда многих исследователей и краеведов, на протяжении многих лет собиравших, фиксировавших, иденти- фицировавших и каталогизировавших разнообразный зоологический материал. Батрахологические коллекции отражают разнообразие фауны амфибий и позволяют проследить основные пути их расселения в конкретный временной промежуток, наглядно демонстрируют механизмы формирования современных ареалов некоторых видов и, что наиболее значимо, позволяют определить тенденции динамики численности и распространения отдельных популяций. Материалы музейных коллекций важны в зоологических исследованиях, так как дают возможность проверить видовую идентификацию и позволяют находить новые признаки у животных, что становится актуальным в свете интенсивного расселения чужеродных видов (Дгебуадзе, 2014) и развития новых методов зоологических исследований.

Зоологический музей Саратовского национального исследовательского государственного университета имени Н. Г. Чернышевского (СГУ), имеющий столетнюю историю, - это уникальное хранилище коллекции земноводных региональной фауны, которая насчитывают более 1000 единиц хранения. Свое начало коллекция берет с момента основания музея в 1909 г. На сегодняшний день здесь сконцентрированы наиболее крупные в Поволжье батрахологические фонды. Значитель- 
ную часть фондов музея составляют мониторинговые коллекции (периодически повторяющиеся сборы с целью выявления изменений в природных сообществах), имеются серийные сборы всех видов бесхвостых амфибий Саратовской области.

\section{КРАТКАЯ ИСТОРИЯ ИЗУЧЕНИЯ} ЗЕМНОВОДНЫХ САРАТОВСКОЙ ОБЛАСТИ И ФОРМИРОВАНИЕ БАТРАХОЛОГИЧЕСКОЙ КОЛЛЕКЦИИ ЗООЛОГИЧЕСКОГО МУЗЕЯ САРАТОВСКОГО УНИВЕРСИТЕТА

Батрахологические исследования в Саратовской области имеют давнюю историю. Изучение животных данной таксономической группы берет свое начало со второй половины XVIII в. Первой опубликованной работой, в которой приведены сведения о земноводных территории Оренбургской губернии, является изданная П. И. Рычковым в 1762 г. «Топография Оренбургская, то есть: обстоятельное описание Оренбургской губернии, сочиненное коллежским советником и Императорской Академии наук корреспондентом Петром Рычковым» (Рычков, 1762). Она была переиздана в 1887 г. под названием «Топография Оренбургской губернии» (Рычков, 1887). В последующий период познание герпетофауны региона связано с «физическими» экспедициями (1768-1775 гг.) отрядов И. И. Лепехина, И. П. Фалька, П. С. Паласса и И. Г. Георги.

Земноводные Поволжья и сопредельных регионов отмечаются в дневниковых записях и сочинениях П. С. Палласа (Pallas, 1771, 1776), а также в работах участников экспедиций И. П. Фалька и И. Г. Георги (Никольский, 1918; Гаранин, 1983). В частности, И. Г. Георги отмечал «водяную лягушку», видимо, называя так озёрную лягушку, и чесночницу под биноменом Rana vespertina, a П. И. Фальк - краснобрюхую жерлянку.

Наибольший вклад в исследования земноводных региона внес П. С. Паллас, в работах которого отмечаются амфибии в восточной (левобережной) части Среднего Поволжья. В первой части труда «Путешествие по разным провинциям Российской Империи» он описывает с территории нынешней Самарской области «вечернюю лягушку» - Rana vespertina (Паллас, 1773). В третьей части названного труда П. С. Паллас отмечает 1 вид лягушек у р. Ток (окрестности д. Игнашкино на территории Оренбургской области), рек Урал и Волги (Паллас, 1788). П. С. Паллас указывает на обилие данного вида в водах рек и озер и применяет к ним эпитет «кричащая», что дает право утверждать, что речь идет об озёрной лягушке - наиболее многочисленном виде региона с характерной вечерней звуковой активностью.
После публикации третьего тома «Zoographia Rosso-Asiatica» (Pallas, [1814]) сведения о земноводных Среднего Поволжья появляются в научной литературе только в последней трети XIX в. М. Н. Богданов (1871) упоминает «лягушек» в питании птиц (чёрного коршуна) на территории Симбирской губернии. Первой подробной сводкой о земноводных Нижнего Поволжья можно считать обзор фауны имения Падов Саратовской губернии А. А. Силантьева, вышедшей в свет в 1894 г. В ней приводится список из 6 видов амфибий, а также видовые очерки земноводных с указанием особенностей их биологии и экологии (Силантьев, 1894). В них содержится информация о численности и распространении, фенологических особенностях амфибий с территории Саратовской губернии. А. А. Силантьев приводит сведения о тритоне пятнистом (Triton taeniatus), чесночнице обыкновенной (Pelobates fuscus), жерлянке огненной (Bombinator igneus), жабе пятнистой (Bufo variabilis), лягушке серой (Rana arvalis), лягушке зелёной (R. esculenta). Опираясь на подробное описание отдельных видов, можно предположить, что речь идет о таких современных видах амфибий, как тритон обыкновенный, чесночница обыкновенная, жерлянка краснобрюхая, зелёная жаба, лягушка остромордая. По всей видимости, зелёная лягушка, описанная А. А. Силантьевым, - это озёрная лягушка, которая в то время отождествлялась с R. esculenta.

Б. М. Житков (1900) в статье «Очерки природы Среднего Поволжья» перечисляет 7 видов амфибий. Зелёные лягушки упоминаются как 1 вид «Rana esculenta», бурые - также объединены в 1 вид, но выделены так называемые вариации, соответствующие остромордой и травяной лягушкам «Ranae [Rana] temporariae var. arvalis et muta».

В разделе «Животные земноводныя» справочной книги Пензенской губернии для данного региона указаны 4 вида «лягушек», в том числе квакша под названием «Hyla viridis - Квакуша зелёная» (Попов, 1901). П. А. Ососков с соавторами (1901) в 6-м томе «Среднее и Нижнее Поволжье и Заволжье» многотомного издания «Россия. Полное географическое описание нашего Отечества» кратко описывают батрахофауну региона.

Главным итогом батрахологических исследований в России начала XX в. является монография А. М. Никольского (1918) «Фауна России и сопредельных стран: Земноводные (Amphibia)», в которой отражены почти все опубликованные к тому времени данные по Среднему Поволжью, а также использованы коллекционные материалы и личные сообщения исследователей, в частности о серой жабе. А. М. Никольский разделил лягушек 
рода Rana на зелёных и бурых. К зелёным лягушкам он отнес съедобную, или водяную лягушку (R. esculenta), дав подробное описание биологии и экологии вида, а также затронул вопросы систематики.

Отдельные упоминания о земноводных саратовского Заволжья можно найти в работах А. Л. Бенинга $(1913,1921)$ по гидрофауне р. Б. Иргиз и р. Еруслан. Составленный В. С. Бажановым «Список гадов Бузулукского и Пугачевского уездов б. Самарской губ., собранных в 1928 году» (1930) содержит сведения о 5 видах бесхвостых земноводных.

Интерес к изучению амфибий и интенсификация исследований на севере Нижнего Поволжья значительно возросли во второй половине ХХ в. (Кубанцев, 1999). Большинство экологических работ посвящено выяснению численности и пространственному распределению особей, структуре и динамике их популяций, использованию биотопа, развитию и питанию. В это время появляются работы С. А. Чернова $(1937,1945)$, П. В. Терентьева и С. А. Чернова (1949), где представлен материал по распространению амфибий в Нижнем Поволжье, приведены картосхемы. Озёрная лягушка отмечена авторами как массовое, широко распространенное земноводное.

В. И. Гаранин (1983) в монографии «Земноводные и пресмыкающиеся Волжско-Камского края» обобщает результаты собственных исследований и литературные данные для территории региона. Им приводятся данные о питании, врагах, экологической дифференциации, фенологии и границах распространения амфибий.

Значительное количество работ, посвященных изучению амфибий Нижнего Поволжья, выполнены на базе Саратовского университета в 1980-е гг. Большинство из них посвящены изучению питания амфибий (Носова, 1984; Шляхтин, 1985 a; Носова и др., 1987; Шляхтин, Завьялов, 1997; Шляхтин и др., 2001 a). В них детально рассмотрены не только экологические аспекты питания (кормовой спектр, индивидуальные предпочтения, сезонные и биотопические особенности питания), но приведены анатомические и гистологические особенности пищеварительной системы большинства видов региональной батрахофауны (Шляхтин, 1980, 1987). В 1986 г. появляется первая методическая работа по земноводным Саратовской области (Шляхтин, Голикова, 1986). В ней приводятся основные сведения об экологии 10 видов амфибий, а также даются рекомендации по сбору и хранению батрахологического материала, по проведению фенетических исследований. В 1990-е гг. основное направление в изучении земноводных
Саратовской области и Нижнего Поволжья в целом связано с фенетической изменчивостью этой группы. Появляется ряд работ, посвященных особенностям окраски, метрическим и меристическим ха-рактеристикам популяций бесхвостых амфибий (Шляхтин, 1985 б; Сторожилова и др., 1998; Сторожилова, Шляхтин, 2000; Табачишин и др., 1999; Сторожилова, 2002). В основу этих работ легли сборы амфибий, хранящихся в Зоологическом музее СГУ. В некоторых публикациях (Завьялов, Табачишин, 1998 ; Табачишин и др., 1997, 2000) детально рассматривается современное распространение фоновых и редких видов рептилий и амфибий в пределах севера Н. Поволжья, анализируется их таксономический статус. Большое внимание в этот период уделяется вопросам адаптации амфибий к антропогенным условиям (Гаранин, 1981; Белянин и др., 1989; Завьялов, Табачишин, $1998 a$; Шляхтин и др., 2001 б).

В пределах Саратовской области также проведено изучение степени деградации амфибий и рептилий островных экосистем Волгоградского водохранилища в условиях экологической изоляции, сделан вывод о незначительном влиянии создания Волгоградского водохранилища на структуру и функционирование наземных и водных экосистем поймы р. Волги (Шляхтин и др., 1994, 20016,2014$)$.

Бесхвостые амфибии и особенно озёрные лягушки становятся модельными объектами в исследованиях действия отравляющих веществ, их используют в качестве индикаторов загрязнения среды различными химическими соединениями (Завьялов и др., 1994, 1996; Шляхтин и др., 1996; Завьялов, Табачишин, $1998 a$ ).

Особый вклад в изучение амфибий региона на рубеже XX - XXI столетий внесли саратовские герпетологи. На основе анализа данных полевых исследований и коллекционных фондов крупнейших зоологических музеев страны появляются публикации, посвященные состоянию популяций отдельных видов рептилий и амфибий в северной части Н. Поволжья (Завьялов, Табачишин, $1998 a$, б; Табачишин и др., 2000; Сторожилова, 2002). С 2003 г. на базе Зоологического музея СГУ проводятся современные цито- и молекулярно-генетические исследования амфибий Нижневолжского региона. Особое внимание уделено видам со сложным систематическим статусом: озёрной лягушке, зелёной жабе и обыкновенной чесночнице (Кайбелева и др., 2004, 2005, 2006, 2010; Полуконова и др., $2013 a, \sigma)$.

В различные годы XIX - XX вв. в литературных источниках состав батрахофауны Поволжья в значительной степени менялся: так, во вто- 
рой половине $\mathrm{XX}$ в. в составе местных амфибий упоминался гребенчатый тритон, травяная, прудовая, съедобная лягушки. Современные исследования не подтверждают присутствие данных видов на территории области.

В основу современной батрахологической коллекции Зоологического музея СГУ легли сборы Волжской биологической станции. Формирование коллекции амфибий началось в 1900 г. и включали виды местной батрахофауны: 1 вид хвостатых амфибий - Обыкновенный тритон (с указанием старого латинского названия Molge vulgaris L.). По одному виду жаб и чесночниц - зелёная жаба и чесночница обыкновенная. Из лягушек в трудах Волжской биологической станции приведены латинские названия трех видов: Rana arvalis Nilss., $R$. temporaria Schn., $R$. esculenta L. Вероятно, речь идет о двух современных видах озёрной и остромордой лягушках, широко распространенных в Саратовской области. С 1909 г. с момента открытия Зоологического музея СГУ (тогда - зоологического кабинета) происходило формирование экспозиционной и учебной коллекции амфибий - чучела, скелеты и спиртовые препараты выписывались даже из заграницы. Научную коллекцию Зоологического музея СГУ составляли виды исключительно местной батрахофауны. Пополнение коллекции амфибий видами с других территорий началось в 1920 -е гг. и связано с работами Камыш-Самарской экспедиции $1926-$ 1929 гг. В 1930-х гг. с расширением Зоологического музея СГУ продолжает регулярно пополняться и батрахологическая коллекция (в основном учебная). Примерно в это же время Волжская биологическая станция передала часть собственных сборов, включая земноводных, Зоологическому музею СГУ. Формирование серийных сборов амфибий, составивших значительную часть коллекционных фондов, интенсифицировалось к середине XX в. и связано с развитием экологических направлений, особенно фенетических исследований, на кафедре зоологии позвоночных.

К сожалению, большая часть старых фондов была утеряна в основном из-за отсутствия специальных работ, направленных на поддержание и сохранение коллекционных материалов. Значительная часть коллекции погибла в огне от пожара в 1992 г. Восстановление коллекций земноводных началось лишь в конце XX в. В настоящее время ведется активная работа, направленная на поддержание и пополнение современной научной батрахологической коллекции Зоологического музея Саратовского национального исследовательского государственного университета имени Н. Г. Чернышевского.

\section{КАТАЛОГ БАТРАХОЛОГИЧЕСКИХ СБОРОВ, ПРОИЗВЕДЕННЫХ НА ТЕРРИТОРИИ САРАТОВСКОЙ ОБЛАСТИ}

\author{
КЛАСС АМФИБИИ,
}

ИЛИ ЗЕМНОВОДНЫЕ - АМРНІВІА

Отряд Хвостатые - Caudata

Fischer von Waldheim, 1813

Семейство Саламандровые - Salamandridae Goldfuss, 1820

Род Малый (гладкий) тритон Lissotriton Bell, 1839

Обыкновенный тритон - Lissotriton vulgaris (Linnaeus, 1758).

Статус. Обычный вид.

Коллекиионныйматериал ( $n=29)$ (рис. 1).

1. № 6557. 03.05.2000 г. 1 M. ad. Саратовская обл., Аркадакский р-н, с. Семеновка. К. Д. Мильто, А. В. Барабанов (ЗИН РАН).

2. № 120/1073 - 1076. 10.05.2002 г. 3 M., 1 F. ad. Саратовская обл., окрестности г. Хвалынска. В. Г. Табачишин (ЗМ СГУ).

3. № 126/1102. 10.05.2004 г. Саратовская обл., окрестности г. Хвалынск. В. Г. Табачишин (ЗМСГУ).

4. № 318/1759-1760. 13.05.2009 г. Саратовская обл., окрестности г. Хвалынска (урочище Таши). Э. И. Кайбелева (ЗМ СГУ).

5. № 248/1488-1492. 20.04.2010 г. Саратовская обл., Лысогорский р-н, окрестности с. Урицкое (оз. Лебяжье). М. В. Ермохин (ЗМ СГУ).

6. № 250/1494-1495. 11.05.2010 г. Саратовская обл., окрестности г. Саратова. М. Ю. Воронин (ЗМСГУ).

7. № 317/1758. 11.07.2011 г. Саратовская обл., Лысогорский р-н, окрестности с. Атаевка. В. Г. Табачишин (ЗМ СГУ).

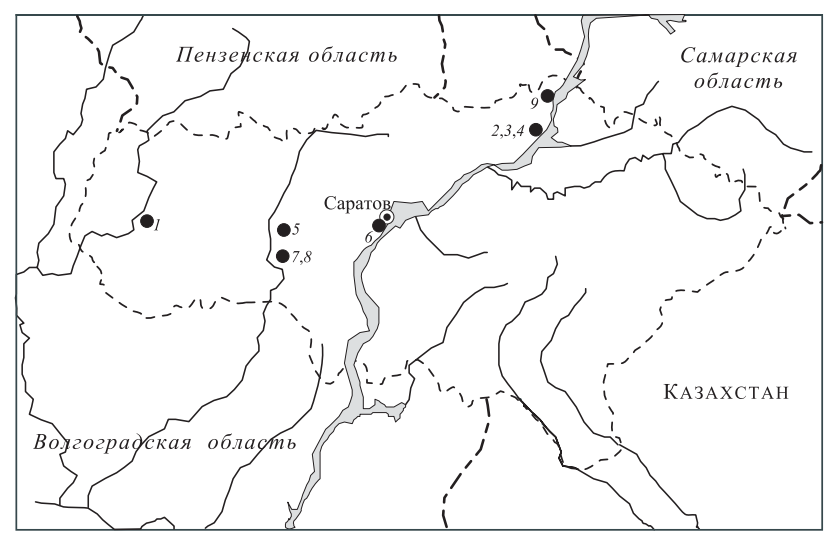

Рис. 1. Кадастр сборов тритона обыкновенного в Саратовской области. Географическую привязку см. в тексте Fig. 1. Cadastre of the Lissotriton vulgaris collections in the Saratov region. See geographical association in the text 
8. № 333/1817-1818. 23.08.2011 г. Саратовская обл., Лысогорский р-н, окрестности с. Атаевка. В. Г. Табачишин (ЗМ СГУ).

9. № 327/1797-1807. 28.06.2012 г. Саратовская обл., Хвалынский р-н, окрестности пос. Черный Затон. Э. И. Кайбелева (ЗМ СГУ).

Отряд Бесхвостые земноводные - Anura Fischer von Waldheim, 1813

Семейство Жерлянки - Bombinatoridae Gray, 1825

Род Жерлянка - Bombina Oken, 1816

Краснобрюхая жерлянка - Bombina bombina (Linnaeus, 1761).

Cтатус. Обычный вид.

Коллекиионный материал ( $n=308)$ (рис. 2).

1. № 3/7-10. 30.04.1989 г. Саратовская обл., Краснокутский p-н, окрестности с. Дьяковка. А. Н. Белянин (ЗМ СГУ).

2. № 4/11-13. 03.05.1989 г. Саратовская обл., Перелюбский р-н, окрестности с. Алексеевка. А. В. Николаев (ЗМ СГУ).

3. № 11/32-37. 27.07.1989 г. 6 M. ad. Capaтовская обл., Самойловский р-н, окрестности с. Красавка. А. С. Усов (ЗМ СГУ).

4. № 13/40.29.07.1989 г. 1 М. ad. Саратовская обл., Самойловский р-н, окрестности с. Еловатка. А. С. Усов (ЗМ СГУ).

5. № 15/43-48. 20.07.1990 г. 4 F. ad. 1 S. juv. Саратовская обл., Романовский р-н, окрестности с. Усть-Щербидино. В. В. Викторова (ЗМ СГУ).

6. № 20/60-61. 03.07.1991 г. 1 F., 1 M. ad. Саратовская обл., Екатериновский р-н, окрестности с. Качеевка (долина р. Аткара). Е. А. Соловьева (ЗМСГУ).

7. № 35/138-144. 28.06.1996 г. 3 F., 4 M. ad. Саратовская обл., Краснокутский р-н, окрестности с. Дьяковка. К. А. Сонин (ЗМ СГУ).

8. № 43/169-197. 01.09.1996 г. Саратовская обл., Энгельсский р-н, пос. ВолжНИИГ и М. Д. А. Сторожилова (ЗМ СГУ).

9. № 46/202-305. 07.05.1997 г. Саратовская обл., Аркадакский р-н, окрестности с. Семеновка (пойма р. Хопер). В. Г. Табачишин, Д. А. Сторожилова (ЗМ СГУ)

10. № 6559. 01-05.05.2000 г. 34 S. Саратовская обл., Аркадакский р-н, с. Семеновка (левый берег р. Хопер). К. Д. Мильто, А. В. Барабанов (ЗИН РАН).

11. № 97/716-757. 08.08.2000 г. Саратовская обл., Краснокутский р-н, окрестности с. Дьяковка. Д. А. Сторожилова (ЗМ СГУ).

12. № 107/919-920. 22.04.2001 г. Саратовская обл., Энгельсский р-н, окрестности ж.-д. ст. Анисовка. К. А. Сонин (ЗМСГУ).
13. № 6943. 19.05.2002 г. 13 S. Саратовская обл., Балашовский р-н, с. Исток. Г. А. Лада (ЗИН $\mathrm{PAH})$.

14. № 6986. 14.06.2002 г. 24 S. Саратовская обл., Лысогорский р-н, окрестности с. Белое озеро. Г. А. Лада (ЗИН РАН).

15. № 127/1103. 10.05.2004 г. Саратовская обл., окрестности г. Хвалынска. В. Г. Табачишин (ЗМСГУ).

16. № 146/1138. 15.08.2005 г. Саратовская обл., окрестности г. Хвалынска (урочище Таши). К. А. Сонин (ЗМ СГУ).

17. № 156/1154-1156. 26.08.2008 г. Саратовская обл., Пугачевский р-н, окрестности с. Каменка (пойма р. Большой Иргиз). Е. В. Завьялов (ЗМ СГУ).

18. № 319/1761-1764. 13.05.2009 г. Саратовская обл., окрестности г. Хвалынска (урочище Таши). Э. И. Кайбелева (ЗМ СГУ).

19. № 303/1715. 26.04.2011 г. Саратовская обл., Лысогорский р-н, окрестности с. Атаевка (оз. Б. Коблово). В. Г. Табачишин (ЗМ СГУ).

20. № 309/1732-1734 26.04.2011 г. Саратовская обл., Лысогорский р-н, окрестности с. Атаевка. В. Г. Табачишин, М. В. Ермохин (ЗМ СГУ).

21. № 300/1671. 02.05.2011 г. Саратовская обл., Лысогорский р-н, окрестности с. Атаевка. В. Г. Табачишин, М. В. Ермохин (ЗМ СГУ).

22. № 307/1725. 02.05.2011 г. Саратовская обл., Лысогорский р-н, окрестности с. Атаевка (оз. Б. Коблово). В. Г. Табачишин, М. В. Ермохин (ЗМСГУ).

23. № 308/1726-1731. 02.05.2011 г. Саратовская обл., Лысогорский р-н, окрестности с. Атаевка. В. Г. Табачишин, М. В. Ермохин (ЗМ СГУ).

24. № 344/1863-1865. 08.04.2013 г. Саратовская обл., Лысогорский р-н, окрестности с. Урицкое. В. Г. Табачишин (ЗМ СГУ).

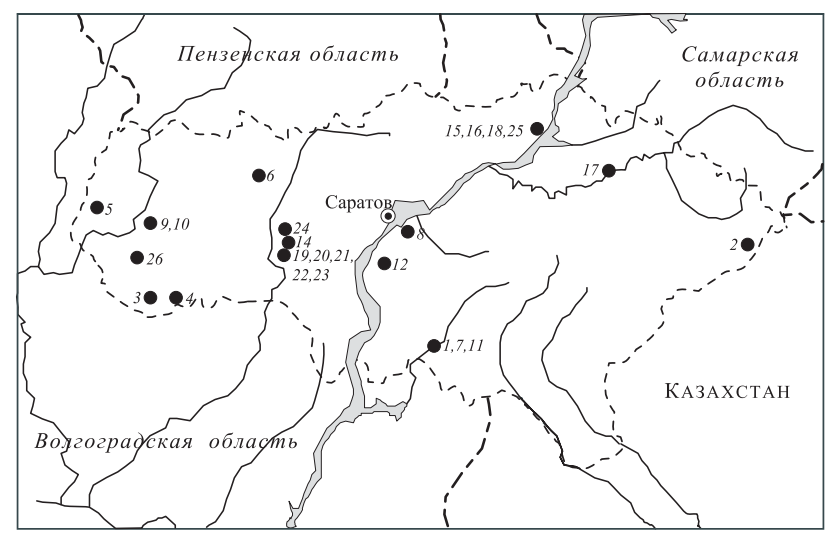

Рис. 2. Кадастр сборов жерлянки краснобрюхой в Саратовской области. Географическую привязку см. в тексте Fig. 2. Cadastre of the Bombina bombina collections in the Saratov region. See geographical association in the text 
25. № 352/1936-1937. 24.06.2013 г. Саратовская обл., окрестности г. Хвалынска (урочище Таши). Э. И. Кайбелева (ЗМ СГУ).

26. № 353/1938-1941. 23.07.2013 г. Саратовская обл., Балашовский р-н, окрестности с. Пинеровка. Э. И. Кайбелева (ЗМ СГУ).

Семейство Чесночницы -

Pelobatidae Bonaparte, 1830

Род Чесночница - Pelobates Wagler, 1830

Обыкновенная чесночница - Pelobates fuscus (Laurenti, 1768).

Статус. Обычный вид.

Коллекиионныйматериал ( $n=445)$ (рис. 3).

1. № 9/29-30. 26.07.1989 г. Саратовская обл., Самойловский р-н, с. Красавка. Д. А. Сторожилова (ЗМСГУ).

2. № 12/38-39. 28.07.1989 г. Саратовская обл., Самойловский р-н, с. Еловатка. Д. А. Сторожилова (ЗМ СГУ).

3. № 17/56. 20.07.1990 г. Саратовская обл., Романовский р-н, окрестности с. Усть-Щербидино. В. В. Викторова (ЗМ СГУ).

4. № 21/62.03.07.1991 г. 1 M. ad. Саратовская обл., Екатериновский р-н, с. Качеевка. Д. А. Сторожилова (ЗМСГУ).

5. № 24/113. 18.07.1991 . 1 F. ad. Саратовская обл., Воскресенский р-н, окрестности с. Воскресенское. В. Г. Табачишин (ЗМ СГУ).

6. № 29/123. 03.05.1996 г. 1 F. ad. Саратовская обл., Аркадакский р-н, с. Семеновка. В. Г. Табачишин (ЗМ СГУ).

7. № 32/127. 22.06.1996 г. Саратовская обл., Энгельсский р-н, пос. ВолжНИИГ и М. Д. А. Сторожилова (ЗМСГУ).

8. № 34/133-137. 28.06.1996 г. 2 M., 2 F. ad., 1 S. juv. Саратовская обл., Краснокутский р-н,

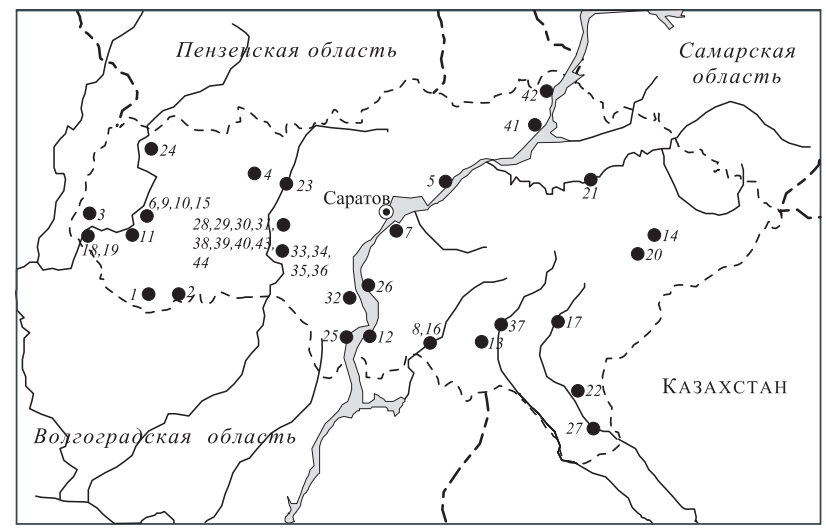

Рис. 3. Кадастр сборов чесночницы обыкновенной в Саратовской области. Географическую привязку см. в тексте Fig. 3. Cadastre of the Pelobates fuscus collections in the Saratov region. See geographical association in the text окрестности с. Дьяковка. К. А. Сонин (ЗМ СГУ).

9. № 45/201. 05.05.1997 г. Саратовская обл., Аркадакский р-н, окрестности с. Семеновка. В. Г. Табачишин, Д. А. Сторожилова (ЗМ СГУ).

10. №199/1268-1347. 05.05.1997 г. Саратовская обл., Аркадакский р-н, с. Семеновка. В. Г. Табачишин, Д. А. Сторожилова (ЗМ СГУ).

11. № 2144. 05-07.05.1997 г. 10 S. Саратовская обл., Аркадакский р-н, окрестности с. Летяжевка (пойма р. Хопер). В. Г. Табачишин (3М ННПМ НАНУ).

12. № 48/334. 23.05.1997 г. Саратовская обл., Ровенский р-н, окрестности пос. Ровное. В. Г. Табачишин (ЗМ СГУ).

13. № 83/570-590. 12.06.1999 г. Саратовская обл., Краснокутский р-н, окрестности пос. Комсомольское (пойма р. Жидкая Солянка). В. Г. Табачишин (ЗМ СГУ).

14. № 92/703-710. 30.08.1999 г. Саратовская обл., Краснопартизанский р-н, окрестности пос. Целинный. Т. А. Капранова (ЗМ СГУ).

15. № 6558. 01.05.2000 г. 1 S. Саратовская обл., Аркадакский р-н, с. Семеновка. К. Д. Мильто, А. В. Барабанов (ЗИН РАН).

16. № 98/758-806. 12.08.2000 г. Саратовская обл., Краснокутский р-н, окрестности с. Дьяковка. В. Г. Табачишин (ЗМ СГУ).

17. № 101/870-873. 19.09.2000 г. Саратовская обл., Новоузенский р-н, окрестности с. Куриловка. В. Г. Табачишин (ЗМ СГУ).

18. № 6931. 18.05.2002 г. 23 S. Саратовская обл., Балашовский р-н, с. Рассказань. Г. А. Лада (ЗИН РАН).

19. № 6962. 18.05.2002 г. 5 S. Саратовская обл., Балашовский р-н, с. Рассказань. Г. А. Лада (ЗИН РАН).

20. № 113/459. 29.04.2003 г. 1 S. ad. Саратовская обл., Дергачевский р-н, окрестности пос. Прудовой. А. И. Файзулин (ИЭВБ РАН).

21. № 151/1144. 05.05.2006 г. Саратовская обл., Пугачевский р-н, окрестности с. Каменка (пойма р. Большой Иргиз). Э. И. Кайбелева (3М СГУ).

22. № 155/1151-1153. 13.05.2006 г. Саратовская обл., Александровогайский р-н, окрестности пос. Монахов. В. Г. Табачишин (ЗМ СГУ).

23. № 157/1157. 17.05.2006 г. Саратовская обл., Аткарский р-н, окрестности с. Приречное (пойма р. Медведица). Э. И. Кайбелева (ЗМ СГУ).

24. № 160/1165-1168. 17.05.2006 г. Саратовская обл., Ртищевский р-н, окрестности с. Владыкино (пойма р. Хопер). К. А. Сонин (ЗМ СГУ).

25. № 178/1215-1216. 04.10.2006 г. Саратовская обл., Красноармейский р-н, окрестности с. Золотое. Е. В. Завьялов (ЗМ СГУ). 
26. № 179/1217-1218. 05.10.2006 г. Саратовская обл., Ровенский р-н, окрестности с. Приволжское. М. Г. Корнеев (ЗМ СГУ).

27. №214/1393-1395. 10.05.2008 г. Саратовская обл., окрестности пос. Александров Гай. Е. В. Завьялов (ЗМ СГУ).

28. № 259/1523-1592. 15.05.2009 г. Саратовская обл., Лысогорский р-н, окрестности с. Урицкое (оз. Лебяжье). М. В. Ермохин (ЗМ СГУ).

29. № 249/1493. 15.04.2010 г. Саратовская обл., Лысогорский р-н, окрестности с. Урицкое (оз. Лебяжье). Э. И. Кайбелева (ЗМ СГУ).

30. № 269/1609-1625. 20.04.2010 г. Саратовская обл., Лысогорский р-н, окрестности с. Урицкое. М.В. Ермохин (ЗМ СГУ).

31. № 260/1593. 12.07.2010 г. Саратовская обл., Лысогорский р-н, окрестности с. Урицкое (оз. Лебяжье). М. В. Ермохин (ЗМ СГУ).

32. № 252/1500. 08.07.2010 г. Саратовская обл., Красноармейский р-н, окрестности с. Садовое. К. А. Сонин (ЗМ СГУ).

33. № 302/1711-1714. 26.04.2011 г. Саратовская обл., Лысогорский р-н, окрестности с. Атаевка (оз. Б. Коблово). М. В. Ермохин, В. Г. Табачишин (ЗМ СГУ).

34. № 310/1735-1745. 26.04.2011 г. Саратовская обл., Лысогорский р-н, окрестности с. Атаевка. М. В. Ермохин, В. Г. Табачишин (ЗМ СГУ).

35. № 301/1672-1710. 03.05.2011 г. Саратовская обл., Лысогорский р-н, окрестности с. Атаевка. М. В. Ермохин, В. Г. Табачишин (ЗМ СГУ).

36. № 306/1721-1724. 03.05.2011 г. Саратовская обл., Лысогорский р-н, окрестности с. Атаевка (оз. Б. Коблово). М. В. Ермохин, В. Г. Табачишин (ЗМ СГУ).

37. № 314/1753. 05.07.2011 г. Саратовская обл., Питерский р-н, окрестности с. Питерка (р. М. Узень). Т. В. Перевозникова (ЗМ СГУ).

38. № 335/1820-1834. 13.04.2012 г. Саратовская обл., Лысогорский р-н, окрестности с. Урицкое (оз. Кругленькое). М. В. Ермохин (ЗМ СГУ).

39. № 336/1835-1838. 13.04.2012 г. Саратовская обл., Лысогорский р-н, окрестности с. Урицкое (оз. Садок). М. В. Ермохин (ЗМ СГУ).

40. № 337/1839-1853. 14.04.2012 г. Саратовская обл., Лысогорский р-н, окрестности с. Урицкое. М. В. Ермохин (ЗМ СГУ).

41. № 330/1812. 26.06.2012 г. Саратовская обл., окрестности г. Хвалынска (верховое болото). Э. И. Кайбелева (ЗМ СГУ).

42. № 328/1808-1810. 28.06.2012 г. Саратовская обл., Хвалынский р-н, окрестности с. Черный Затон. Э. И. Кайбелева (ЗМ СГУ).

43. № 345/1866-1871. 08.04.2013 г. Саратовская обл., Лысогорский р-н, окрестности с. Уриц- кое. В. Г. Табачишин (ЗМ СГУ).

44. № 347/1887-1898. 14.04.2013 г. Саратовская обл., Лысогорский р-н, окрестности с. Урицкое. В. Г. Табачишин (ЗМ СГУ).

Семейство Жабы - Bufonidae Gray, 1825 Род Жаба - Bufo Laurenti, 1768

Зелёная жаба - Bufo viridis Laurenti, 1768.

Cтатус. Обычный вид.

Коллекиионныйматериал ( $n=218)$ (рис. 4).

1. № 6589. 1879 г. 5 S. Саратовская обл., Аткарский р-н. Грум-Гржимайло (ЗИН РАН).

2. № 5/14-19.03.05.1989 г. 6 M. ad. Саратовская обл., Перелюбский р-н, окрестности с. Алексеевка. А. В. Николаев (ЗМ СГУ).

3. № 10/31.26.07.1989 г. 1 M. ad. Саратовская обл., Самойловский р-н, окрестности с. Красавка. А. С. Усов (ЗМ СГУ).

4. № 14/41-42. 29.07.1989 г. Саратовская обл., Самойловский р-н, окрестности с. Еловатка. А. С. Усов (ЗМ СГУ).

5. № 23/65-112. 08.07.1991 г. Саратовская обл., Краснокутский р-н, окрестности с. Дьяковка. К. А. Сонин (ЗМ СГУ).

6. № 26/115. 25.07.1991 г. Саратовская обл., Воскресенский р-н, окрестности с. Воскресенское. В. В. Ионова (ЗМ СГУ).

7. № 33/128-132. 26.06.1996 г. 4 M. ad., 1 S. juv. Саратовская обл., Краснокутский р-н, окрестности с. Дьяковка. К. А. Сонин (ЗМ СГУ).

8. № 37/149. 21.07.1996 г. 1 M. ad. Саратовская обл., Базарно-Карабулакский р-н, окрестности с. Тепляковка. А. В. Пудовкин (ЗМ СГУ).

9. № 38/150-152. 04.08.1996 г. 1 M. ad. 2 S. juv. Саратовская обл., Ровенский р-н, окрестности пос. Ровное. Д. А. Сторожилова (ЗМ СГУ).

10. № 44/198-200. 05.09.1996 г. Саратовская обл., Энгельсский р-н, пос. ВолжНИИГ и М. Д. А. Сторожилова (ЗМ СГУ).

11. № 50/339-352. 28.06.1997 г. Саратовская обл., Ровенский р-н, окрестности пос. Ровное. В. Г. Табачишин (3М СГУ).

12. № 52/354-360. 17.07.1997 г. Саратовская обл., Ровенский р-н, пос. Ровное. В. Г. Табачишин (ЗМ СГУ).

13. № 60/402-413. 06.09.1997 г. Саратовская обл., Ровенский р-н, окрестности с. Кривояр (пойма р. Бизюк). В. Г. Табачишин (ЗМ СГУ).

14. № 2145. 06.09.1997 г. 9 S. Саратовская обл., Ровенский р-н, окрестности пос. Ровное. В. Г. Табачишин (ЗМ ННПМ НАНУ).

15. № 67/495-499. 25.09.1997 г. Саратовская обл., окрестности г. Балаково. О. В. Котняков (3М СГУ).

16. № 82/569. 27.02.1999 г. Саратовская обл., 
окрестности г. Саратова. Д. А. Сторожилова (3М СГУ).

17. № 96/715. 07.05.2000 г. Саратовская обл., Энгельсский р-н, окрестности ж.-д. ст. Анисовка. Д. А. Сторожилова (ЗМ СГУ).

18. № 100/846-869. 14.08.2000 г. 15 F., 10 M. ad. Саратовская обл., Краснокутский р-н, окрестности с. Дьяковка. Д. А. Сторожилова (ЗМ СГУ).

19. № 114/1001. 15.05.2001 г. Саратовская обл., Саратовский р-н, окрестности с. БуркинБуерак. В. В. Аникин (ЗМ СГУ).

20. № 149/1142. 15.04.2006 г. Саратовская обл., Краснокутский р-н, окрестности с. Дьяковка. В. Г. Табачишин (ЗМ СГУ).

21. № 161/1169. 18.05.2006 г. Саратовская обл., Воскресенский р-н, с. Елшанка. С. Феклистова (ЗМ СГУ).

22. № 162/1170-173. 10.06.2006 г. Саратовская обл., Пугачевский р-н, с. Каменка (пойма р. Большой Иргиз). К. А. Сонин (ЗМ СГУ).

23. № 169/1195. 27.07.2006 г. Саратовская обл., Новобурасский р-н, окрестности с. Радищево (пойма р. Чардым). Е. В. Семенушкина (ЗМ СГУ).

24. № 172/1199. 29.08.2006 г. Саратовская обл., Саратовский р-н, окрестности ст. Жасминная. Ю. В. Иванова (ЗМ СГУ).

25. № 174/1206. 01.10.2006 г. Саратовская обл., окрестности пос. Нов. Бурасы. Л. В. Мещерякова (ЗМ СГУ).

26. № 175/1207-1211. 02.10.2006 г. Саратовская обл., Хвалынский р-н, окрестности г. Хвалынска. Е. В. Завьялов (ЗМ СГУ).

27. № 177/1213-1214. 03.10.2006 г. Саратовская обл., Краснокутский р-н, окрестности г. Красный Кут. Е. В. Завьялов (ЗМ СГУ).

28. № 191/1249. 06.07.2007 г. Саратовская обл., окрестности г. Саратова. Е. В. Завьялов (ЗМ СГУ).

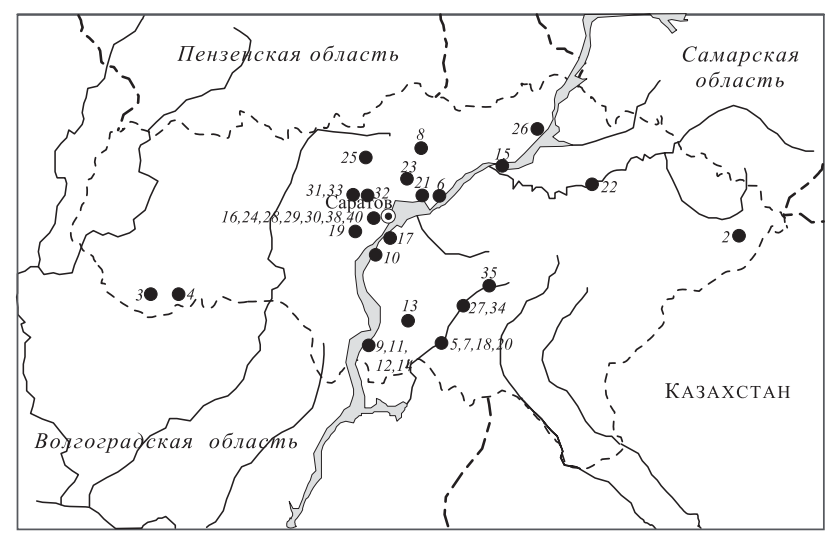

Рис. 4. Кадастр сборов жабы зелёной в Саратовской области. Географическую привязку см. в тексте

Fig. 4. Cadastre of the Bufo viridis collections in the Saratov region. See geographical association in the text
29. № 203/1356. 23.10.2007 г. Саратовская обл., окрестности г. Саратова. Г. В. Шляхтин (3М СГУ).

30. № 197/1266. 11.02.2008 г. Саратовская обл., г. Саратов. М. Ю. Воронин (ЗМ СГУ).

31. № 213/1392. 11.05.2008 г. Саратовская обл., Саратовский р-н, окрестности д. Атамановка. Я. Круглова (ЗМ СГУ).

32. № 215/1396-1399. 12.05.2008 г. Саратовская обл., Саратовский р-н, окрестности с. Сторожевка. А. В. Вошурина (ЗМ СГУ).

33. № 217/1403-1409. 16.05.2008 г. Саратовская обл., Татищевский р-н, окрестности д. Атамановка. А. В. Вошурина (ЗМ СГУ).

34. № 238/1454-1459. 19.04.2009 г. Саратовская обл., Краснокутский р-н, окрестности г. Красный Кут. Петрова (ЗМ СГУ).

35. № 239/1460-1469. 19.04.2009 г. Саратовская обл., Федоровский р-н, окрестности с. Семеновка. В. Сигнаевский (ЗМ СГУ).

36. № 240/1470-1472. 19.04.2009 г. Саратовская обл., Петровский р-н. Е. В. Тишина (ЗМ СГУ).

37. № 241/1473-1478. 19.04.2009 г. Саратовская обл., Ершовский р-н (ЗМ СГУ).

38. № 242/1479-1480. 15.06.2009 г. Саратовская обл., окрестности г. Саратова. В. В. Аникин (ЗМСГУ).

39. № 311/1746-1748. 05.07.2011 г. Саратовская обл., Питерский р-н, (р. Малый Узень). Т. В. Перевозникова (ЗМ СГУ).

40. № 324/1770-1790. 10.05.2012 г. Саратовская обл., г. Саратов. Д. Красников (ЗМ СГУ).

Семейство Лягушки - Ranidae Rafinesque, 1814 Род Бурая (травяная) лягушка Rana Linnaeus, 1758

Остромордая лягушка - Rana arvalis Nilsson, 1842

Статус. Обычный вид.

Коллекиионныйматериал ( $n=240)$ (рис. 5).

1. № 6603. 1880 г. 1 S. Саратовская обл., Аткарский р-н. Грум-Гржимайло (ЗИН РАН).

2. № 6/20-22. 04.05.1989 г. 3 S. juv. Саратовская обл., Перелюбский р-н, окрестности с. Алексеевка. А. В. Николаев (ЗМ СГУ).

3. № 8/25-28.26.07.1989 г. Саратовская обл., Самойловский р-н, окрестности с. Красавка. А. С. Усов (ЗМ СГУ).

4. № 16/49-55. 20.07.1990 г. Саратовская обл., Романовский р-н, окрестности с. Усть-Щербидино. В. В. Викторова (ЗМ СГУ).

5. №25/114. 20.07.1991 г. Саратовская обл., Воскресенский р-н, окрестности с. Медяникова (пойма р. Терешка). Е. В. Соловьева (ЗМ СГУ). 
6. № 36/145-148. 30.06.1996 г. Саратовская обл., Краснокутский р-н, окрестности с. Дьяковка. К. А. Сонин (ЗМ СГУ).

7. № 40/155-157. 20.08.1996 г. Саратовская обл., Ртищевский р-н, окрестности ж.-д. ст. Благодатка. В. Г. Табачишин (ЗМ СГУ).

8. № 47/306-333. 10.05.1997 г. Саратовская обл., Аркадакский р-н, окрестности с. Семеновка (пойма р. Хопер). В. Г. Табачишин, Д. А. Сторожилова (ЗМ СГУ).

9. № 66/488-494. 06.09.1997 г. Саратовская обл., Ровенский р-н, окрестности с. Кривояр (пойма р. Бизюк). Е. В. Завьялов (ЗМ СГУ).

10. № 200/1348. 06.09.1997 г. Саратовская обл., Ровенский р-н, окрестности с. Кривояр (пойма р. Бизюк). Е. В. Завьялов (ЗМ СГУ).

11. № 84/591-594. 12.06.1999 г. Саратовская обл., Краснокутский р-н, пос. Комсомольское (пойма р. Жидкая Солянка). В. Г. Табачишин (3М СГУ).

12. № 90/679-681. 14.08.1999 г. Саратовская обл., Воскресенский р-н, окрестности с. Усовка (берег р. Терешка). Е. В. Завьялов (ЗМ СГУ).

13. № 91/682-702. 30.08.1999 . Саратовская обл., Краснопартизанский р-н, окрестности пос. Целинный. Т. А. Капранова (ЗМ СГУ).

14. № 6560. 01-05.05.2000 г. 1 S. Саратовская обл., Аркадакский р-н, с. Семеновка (левый берег р. Хопер). К. Д. Мильто, А. В. Барабанов (ЗИН РАН).

15. № 6698. 01-05.05.2000 г. 11 S. Саратовская обл., Аркадакский р-н, с. Семеновка (р. Хопер). К. Д. Мильто, А. В. Барабанов (ЗИН РАН).

16. № 99/807-845. 13.08.2000 г. Саратовская обл., Краснокутский р-н, окрестности с. Дьяковка. Д. А. Сторожилова (ЗМ СГУ).

17. № 102/874-880. 19.09.2000 г. Саратовская обл., Новоузенский р-н, окрестности с. Таловка. В. Г. Табачишин (ЗМ СГУ).

18. № 104/885-886. 20.09.2000 г. Саратовская обл., Новоузенский р-н, окрестности с. Куриловка. В. Г. Табачишин (ЗМ СГУ).

19. № 105/887-888. 26.09.2000 г. Саратовская обл., Краснопартизанский р-н, окрестности с. Большая Сакма (пойма р. Сакма). В. Г. Табачишин (ЗМ СГУ).

20. № 119/1023-1072. 06.09.2001 г. Саратовская обл., Советский р-н, окрестности с. Мечетное. О. В. Банадык (ЗМ СГУ).

21. № 6929. 16.05.2002 г. 2 S. Саратовская обл., Лысогорский р-н, окрестности с. Белое Озеро. Г. А. Лада (ЗИН РАН).

22. № 6930. 18.05.2002 г. 1 S. Саратовская обл., Балашовский р-н, с. Рассказань. Г. А. Лада (ЗИН РАН).
23. № 116/462-468. 29.04.2003 г. 1 S. sad. 6 S. juv. Саратовская обл., Дергачевский p-н, окрестности пос. Прудовой. А. И. Файззулин (ИЭВБ $\mathrm{PAH})$.

24. № 205/1358. 12.05.2004 г. Саратовская обл., окрестности г. Хвалынск. Е. В. Завьялов (ЗМ СГУ).

25. № 131/1108-1112. 15.06.2005 г. Саратовская обл., окрестности г. Вольск. К. А. Сонин (ЗМ СГУ).

26. № 148/1141. 15.10.2005 г. Саратовская обл., Новобурасский р-н, окрестности ж.-д. ст. Бурасы (урочище Моховое болото). К. А. Сонин (3М СГУ).

27. № 152/1145-1147. 05.05.2006 г. Саратовская обл., Пугачевский р-н, окрестности с. Каменка (пойма р. Большой Иргиз). Э. И. Кайбелева (3М СГУ).

28. № 158/1158-1160. 17.05.2006 г. Саратовская обл., Аткарский р-н, окрестности с. Приречное (пойма р. Медведица). Э. И. Кайбелева (ЗМ СГУ).

29. № 164/1178-1184. 10.06.2006 г. Саратовская обл., Пугачевский р-н, окрестности пос. Каменка (пойма р. Большой Иргиз). К. А. Сонин (3М СГУ).

30. № 168/1194. 25.07.2006 г. Саратовская обл., Хвалынский р-н, окрестности с. Ст. Лебежайка. К. А. Сонин (ЗМ СГУ).

31. № 176/1212. 02.10.2006 г. Саратовская обл., Хвалынский р-н, окрестности г. Хвалынска. Е. В.Завьялов (ЗМ СГУ).

32. № 181/1221-1223. 18.04.2007 г. Саратовская обл., Вольский р-н, окрестности пос. Сенной (пойма р. Терешка). Н. Н. Якушев (ЗМ СГУ).

33. № 223/1425. 25.08.2008 г. Саратовская обл., Воскресенский р-н, о-в Чардым. Е. В. Завьялов (ЗМ СГУ).

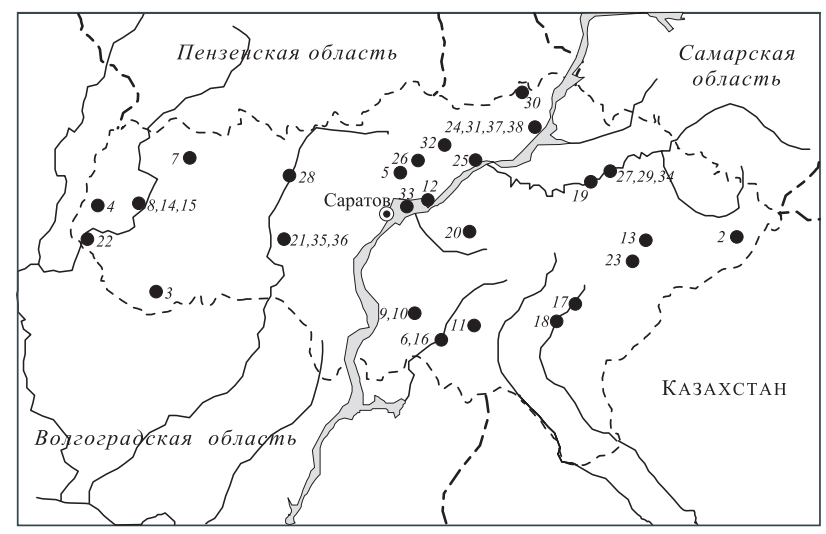

Рис. 5. Кадастр сборов лягушки остромордой в Саратовской области. Географическую привязку см. в тексте Fig. 5. Cadastre of the Rana arvalis collections in the Saratov region. See geographical association in the text 
34. № 225/1431. 06.09.2008 г. Саратовская обл., Пугачевский р-н, окрестности с. Каменка (пойма р. Б. Иргиз). О. А. Помазенко (ЗМ СГУ).

35. № 247/1487. 20.08.2009 г. Саратовская обл., Лысогорский р-н, окрестности с. Белое Озеро. О. А. Помазенко (ЗМ СГУ).

36. № 263/1597. 24.08.2009 г. Саратовская обл., Лысогорский р-н, окрестности с. Белое Озеро. О. А. Помазенко (ЗМ СГУ).

37. № 257/1519. 13.05.2010 г. Саратовская обл., Хвалынский р-н, окрестности г. Хвалынска. Э. И. Кайбелева (ЗМ СГУ).

38. №358/1956. 30.06.2013 г. Саратовская обл., Хвалынский р-н, окрестности г. Хвалынска. О. А. Помазенко (ЗМ СГУ).

\section{Род Зелёная (водная) лягушка - Pelophylax Fitzinger, 1843}

Озёрная лягушка - Pelophylax ridibundus Pallas, 1771.

Статус. Обычный вид.

Коллекиионныйматериал $(n=360)$ (рис. 6).

1. № 7/23-24. 23.07.1989 г. Саратовская обл., Самойловский p-н, окрестности с. Красавка. А. С. Усов (ЗМ СГУ).

2. № 39/153-154. 20.08.1996 г. Саратовская обл., Ртищевский р-н, окрестности ж.-д. ст. Благодатка. В. Г. Табачишин (ЗМ СГУ).

3. № 53/361-365. 18.07.1997 г. Саратовская обл., окрестности г. Саратов. К. А. Сонин (3М СГУ).

4. № 61/414-419. 06.09.1997 г. Саратовская обл., Ровенский р-н, окрестности с. Кривояр (пойма р. Бизюк). Е. В. Завьялов (ЗМ СГУ).

5. № 76/542-549. 09.05.1998 г. Саратовская обл., Энгельсский р-н, окрестности с. Квасниковка. Д. А. Сторожилова (ЗМ СГУ).

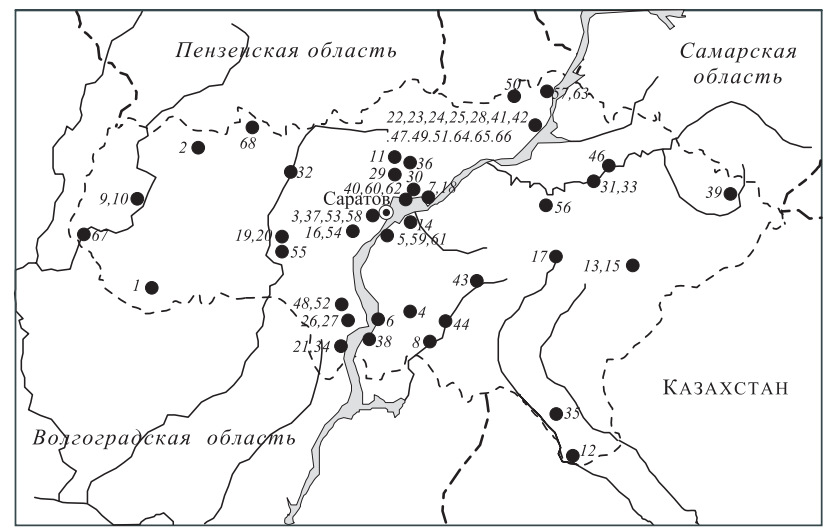

Рис. 6. Кадастр сборов лягушки озёрной в Саратовской области. Географическую привязку см. в тексте Fig. 6. Cadastre of the Pelophylax ridibundus collections in the Saratov region. See geographical association in the text
6. № 85/595-616. 13.06.1999 г. Саратовская обл., Ровенский р-н, пос. Привольное (берег р. Волга). Д. А. Сторожилова (ЗМ СГУ).

7. № 87/625-629. 31.07.1999 г. Саратовская обл., Воскресенский р-н, окрестности с. Усовка (берег р. Терешка). Е. В. Завьялов (ЗМ СГУ).

8. №89/635-678. 11.08.1999 г. Саратовская обл., Краснокутский р-н, окрестности с. Дьяковка. Д. А. Сторожилова (ЗМ СГУ).

9. № 6561. 01-05.05.2000 г. 1 S. Саратовская обл., Аркадакский р-н, с. Семеновка (левый берег р. Хопер). К. Д. Мильто, А. В. Барабанов (ЗИН $\mathrm{PAH})$.

10. № 6697. 01-05.05.2000 г. 6 S. Саратовская обл., Аркадакский р-н, с. Семеновка (левый берег p. Хопер). К. Д. Мильто, А. В. Барабанов (ЗИН $\mathrm{PAH})$.

11. № 106/889-918. 18.03.2001 г. Саратовская обл., Новобурасский р-н, окрестности пос. Аряш (пойма р. Чардым). О. В. Банадык (3М СГУ).

12. № 108/921-927. 11.05.2001 г. Саратовская обл., Александровогайский р-н, окрестности хут. Ветелки. О. В. Банадык (ЗМ СГУ).

13. № 109/928-948. 13.05.2001 г. Саратовская обл., окрестности пос. Дергачи (пойма р. Алтата). О. В. Банадык (ЗМ СГУ).

14. № 111/955-974. 15.05.2001 г. Саратовская обл., Энгельсский р-н, окрестности с. Шумейка. О. В. Банадык (ЗМ СГУ).

15. № 112/975-997. 15.05.2001 г. Саратовская обл., пос. Дергачи (пойма р. Алтата). О. В. Банадык (ЗМ СГУ).

16. № 113/998-1000. 15.05.2001 г. Саратовская обл., Саратовский р-н, окрестности с. Буркин-Буерак. В. В. Аникин (ЗМ СГУ).

17. № 117/1004-1017. 15.08.2001 г. Саратовская обл., Ершовский р-н, с/х Ершовский. О. В. Банадык (ЗМ СГУ).

18. № 118/1018-1022. 16.08.2001 г. Саратовская обл., Воскресенский р-н, окрестности с. Усовка (берег р. Терешка). Е. В. Завьялов (ЗМ СГУ).

19. № 6928. 16.05.2002 г. 1 S. Саратовская обл., Лысогорский р-н, окрестности с. Белое Озеро. Г. А. Лада (ЗИН РАН).

20. № 7380. 16.06.2002 г. 1 S. Саратовская обл., Лысогорский р-н, окрестности с. Белое Озеро. Г. А. Лада (ЗИН РАН).

21. № 139/552. 24.04.2003 г. 1 S. Саратовская обл., Красноармейский р-н, окрестности с. Нижняя Банновка. А. И. Файззулин (ИЭВБ РАН).

22. № 125/1099-1101. 10.05.2004 г. Саратовская обл., Хвалынский р-н, окрестности г. Хвалынск. В. Г. Табачишин (ЗМ СГУ).

23. № 132/1113-1115. 20.06.2005 г. Саратов- 
ская обл., Хвалынский р-н, окрестности г. Хвалынск. Э. И. Кайбелева (ЗМ СГУ).

24. № 133/1116-1120. 20.06.2005 г. Саратовская обл., Хвалынский р-н, окрестности г. Хвалынск (урочище Таши). К. А. Сонин (ЗМ СГУ).

25. № 134/1121. 21.06.2005 г. Саратовская обл., Хвалынский р-н, окрестности г. Хвалынск. Э. И. Кайбелева (ЗМ СГУ).

26. № 138/1126. 10.07.2005 г. Саратовская обл., Красноармейский р-н, окрестности с. Ревино (овраг Студеный, берег р. Волги). К. А. Сонин (3М СГУ).

27. № 139/1127. 10.07.2005 г. Саратовская обл., Красноармейский р-н, окрестности с. Ревино. Э. И. Кайбелева (ЗМ СГУ).

28. № 142/1131-1132. 23.07.2005 г. Саратовская обл., Хвалынский р-н, окрестности г. Хвалынск (урочище Таши). Э. И. Кайбелева (3М СГУ).

29. № 145/1135-1137. 15.08.2005 г. Саратовская обл., Новобурасский р-н, окрестности с. Радищево (пойма р. Чардым). Н. Н. Якушев (ЗМ СГУ).

30. № 147/1139-1140. 20.08.2005 г. Саратовская обл., Воскресенский р-н, окрестности с. Елшанка (о-в Тульский). Е. В. Семенушкина (3М СГУ).

31. № 150/1143. 04.05.2006 г. Саратовская обл., Пугачевский р-н, окрестности с. Каменка (пойма р. Большой Иргиз). Ю. А. Красникова (3М СГУ).

32. № 159/1161-1164. 17.05.2006 г. Саратовская обл., Аткарский р-н, окрестности с. Приречное (пойма р. Медведица). Э. И. Кайбелева (3М СГУ).

33. № 163/1174-1177. 10.06.2006 г. Саратовская обл., Пугачевский р-н, окрестности с. Каменка (пойма р. Большой Иргиз). Э. И. Кайбелева (3М СГУ).

34. № 166/1186-1192. 10.07.2006 г. Саратовская обл., Красноармейский р-н, окрестности с. Ниж. Банновка. Э. И. Кайбелева (ЗМ СГУ).

35. № 173/1200-1205. 25.09.2006 г. Саратовская обл., Александровогайский р-н, хут. Камышки. Е. В. Завьялов (ЗМ СГУ).

36. № 180/1219-1220. 01.04.2007 г. Саратовская обл., Воскресенский р-н, окрестности с. Комаровка. В. Г. Табачишин, Э. И. Кайбелева (ЗМ СГУ).

37. № 88/630-634. 15.06.2007 г. Саратовская обл., г. Саратов (пруд). К. А. Сонин (ЗМ СГУ).

38. № 218/1410-1411. 04.07.2008 г. Саратовская обл., Ровенский р-н, окрестности пос. Ровное. О. А. Помазенко (ЗМ СГУ).

39. № 219/1412-1420. 10.05.2008 г. Саратовская обл., Перелюбский р-н, окрестности с. Перелюб. М. Швецова (ЗМ СГУ).
40. № 224/1426-1430. 25.08.2008 г. Саратовская обл., Воскресенский р-н, о-в Чардым. Е. В. Завьялов (ЗМ СГУ).

41. № 231/1441. 16.10.2008 г. Саратовская обл., Хвалынский р-н, окрестности г. Хвалынск (Святой источник). Е. Ю. Мосолова (ЗМ СГУ).

42. № 232/1442-1447. 16.10.2008 г. Саратовская обл., Хвалынский р-н, окрестности г. Хвалынск (водоем в лесу на территории лагеря). Е. Ю. Мосолова (ЗМ СГУ).

43. № 244/1482-1484 17.04.2009 г. Саратовская обл., Федоровский р-н, окрестности с. Семеновка. Т. В. Перевозникова (ЗМ СГУ).

44. № 245/1485. 19.04.2009 г. Саратовская обл., Краснокутский р-н, окрестности с. Усатово. Т. В. Перевозникова (ЗМ СГУ).

45. № 246/1486. 19.04.2009 г. Саратовская обл., Аткарский р-н (р. Аткара). Т. В. Перевозникова (ЗМ СГУ).

46. № 261/1594-1595. 19.04.2009 г. Саратовская обл., Пугачевский р-н, окрестности г. Пугачев (пойма р. Большой Иргиз). Л. В. Бугреева (3М СГУ).

47. № 251/1496-1499. 14.05.2010 г. Саратовская обл., Хвалынский р-н, окрестности г. Хвалынск. Э. И. Кайбелева (ЗМ СГУ).

48. № 254/1511-1512. 05.07.2010 г. Саратовская обл., Красноармейский р-н, окрестности с. Садовое. М. В. Лаврентьев (ЗМ СГУ).

49. № 255/1513-1516. 13.05.2010 г. Саратовская обл., Хвалынский р-н, окрестности г. Хвалынск. Э. И. Кайбелева (ЗМ СГУ).

50. № 258/1520-1522. 13.05.2010 г. Саратовская обл., Хвалынский р-н, окрестности с. Ст. Лебежайка. Э. И. Кайбелева (ЗМ СГУ).

51. № 256/1517-1518. 14.05.2010 г. Саратовская обл., Хвалынский р-н, окрестности г. Хвалынск. Э. И. Кайбелева (ЗМ СГУ).

52. № 253/1501-1510. 09.07.2010 г. Саратовская обл., Красноармейский р-н, окрестности с. Садовое. К. А. Сонин (ЗМ СГУ).

53. № 265/1604-1605. 26.07.2010 г. Саратовская обл., окрестности г. Саратов. М. Ю. Воронин (ЗМ СГУ).

54. №268/1608. 14.09.2010 г. Саратовская обл., Саратовский р-н, окрестности с. Буркино. О. А. Помазенко (ЗМ СГУ).

55. № 294/1662-1663. 29.04.2011 г. 1 M, 1 F. Саратовская обл., Лысогорский р-н, окрестности с. Урицкое. М. В. Ермохин (ЗМ СГУ).

56. № 304/1716-1717.24.06.2011 г. 2 F. Capaтовская обл., Ершовский р-н, окрестности с. Чапаевка (р. Б. Кушум). Т. В. Перевозникова (ЗМ СГУ).

57. № 305/1718-1720. 14.05.2010 г. 1 M, 2 F. Саратовская обл., Хвалынский р-н, окрестности 
пос. Черный Затон. Э. И. Кайбелева, К. А. Сонин (ЗМ СГУ).

58. № 312/1749-1750. 05.07.2011 г. Саратовская обл., окрестности г. Саратов (Андреевские пруды). Т. В. Перевозникова (ЗМ СГУ).

59. № 313/1751-1752. 05.07.2011 г. Саратовская обл., Энгельсский р-н, окрестности с. Квасниковка. Т. В. Перевозникова (ЗМ СГУ).

60. № 316/1755-1757. 28.08.2011 г. Саратовская обл., Воскресенский р-н, о-в Чардымский. Э. И. Кайбелева (ЗМ СГУ).

61. № 322/1767. 15.04.2012 г. Саратовская обл., Энгельсский р-н, окрестности с. Квасниковка. Т.В. Перевозникова (ЗМ СГУ).

62. № 321/1766. 03.06.2012 г. 1 F. Саратовская обл., Воскресенский р-н, о-в Чардымский. Э. И. Кайбелева (ЗМ СГУ).

63. № 325/1791-1792. 28.06.2012 г. Саратовская обл., Хвалынский р-н, окрестности пос. Черный Затон. Э. И. Кайбелева (ЗМ СГУ).

64. № 326/1793-1796. 29.06.2012 г. 1 M, 2 F. Саратовская обл., Хвалынский р-н, окрестности г. Хвалынск. Э. И. Кайбелева (ЗМ СГУ).

65. № 329/1811. 29.06.2012 г. Саратовская обл., Хвалынский р-н, окрестности г. Хвалынск (урочище Таши). Э. И. Кайбелева (ЗМ СГУ).

66. № 357/1950-1955. 30.06.2013 г. Саратовская обл., Хвалынский р-н, окрестности г. Хвалынск. О. А. Помазенко (ЗМ СГУ).

67. № 360/1958-1960. 21.07.2013 г. Саратовская обл., Балашовский р-н, окрестности с. Алмазово (р. Хопер). К. А. Сонин (ЗМ СГУ).

68. № 359/1957. 22.07.2013 г. Саратовская обл., Ртищевский р-н, окрестности с. Урусово. Э. И. Кайбелева (ЗМ СГУ).

\section{КАТАЛОГ БАТРАХОЛОГИЧЕСКИХ СБОРОВ , ПРОИЗВЕДЕННЫХ ВНЕ ТЕРРИТОРИИ САРАТОВСКОЙ ОБЛАСТИ}

Отряд Хвостатые - Caudata

Fischer von Waldheim, 1813

Семейство Углозубые - Hynobiidae Cope, 1860

Род Сибирские углозубы -

Salamandrella Dibowski, 1870

Сибирский углозуб - Salamandrella keyserlingii Dibowski, 1870.

Коллекиионный материал $(n=4)$ : № 2/3-6. 15.07.1980 г. Новосибирская обл., Северный р-н. А. С. Ишсолаев (ЗМ СГУ).

Семейство Саламандровые - Salamandridae Goldfuss, 1820

Род Саламандра - Salamandra Garsault, 1764
Пятнистая, или огненная саламандра - Salamandra salamandra (Linnaeus, 1758).

Коллекиионный материал $(n=3)$ : № 54/ 366-368. 05.08.1997 г. Украина, Львовская обл., Турковский р-н, окрестности с. Н. Яблоновка. В. Г. Табачишин (ЗМ СГУ).

\section{Род Малый (гладкий) тритон - Lissotriton Bell, 1839}

Обыкновенный тритон - Lissotriton vulgaris (Linnaeus, 1758).

Коллекиионный материал $(n=42)$ : № 51/ 353. 15.07.1997 г. 1 F. ad. Украина, Винницкая обл., окрестности г. Винница. В. Г. Табачишин (3М СГУ). № 70/507-509. 18.04.1998 г. Волгоградская обл., окрестности г. Елань (старица р. Терса). Р. А. Романов (ЗМ СГУ); № 71/510-524. 18.04.1998 г. Волгоградская обл., окрестности г. Елань (карьер). Р. А. Романов (ЗМ СГУ); № 80/562-564. 15.08.1998 г. Украина, Винницкая обл., окрестности г. Винница. В. Г. Табачишин (ЗМ СГУ); № 206/1359-1376. 25.09.2000 г. 3 M., 9 F., ad., 6 S., sad. Украина, Винницкая обл., окрестности г. Винница. В. Г. Табачишин (ЗМ СГУ); № 188/12421243. 21.05.2007 г. Республика Мордовия, Большеигнатовский р-н, окрестности пос. Лесной (НП «Смольный»). А.Б. Ручин (ЗМ СГУ).

$$
\text { Род - Ommatotriton Gray, } 1850
$$

Малоазиатский тритон - Ommatotriton vittatus (Gray, 1835).

Коллекиионный материал $(n=4)$ : № 1/1-2. 01.07.1980 г. 1 М., 1 F. ad. Краснодарский край, Апшеронский p-н, пос. Камышанов (биостанция «Камышанова поляна»). Т. Ю. Пескова (ЗМ СГУ); № 228/1435-1436. 15.07.2007 г. 1 M., 1 F. ad. Kраснодарский край, Апшеронский р-н, пос. Камышанов (биостанция «Камышанова поляна»). С. А. Островских (ЗМ СГУ).

Род Крупный тритон -

Triturus Rafinesque, 1815

Гребенчатый тритон - Triturus cristatus (Laurenti, 1768).

Коллекиионный материал $(n=2)$ : № 189/ 1244-1245. 21.05.2007 г. Республика Мордовия, Большеигнатовский р-н, окрестности пос. Лесной (НП «Смольный») А. Б. Ручин (ЗМ СГУ).

Тритон Карелина - Triturus karelinii (Strauch, 1870).

Коллекиионный материал $(n=5)$ : № 116/ 1003. 22.07.2001 г. Крым, окрестности г. Севастополь. Ю. В. Кармышев (ЗМ СГУ); № 227/14331434. 15.04.2006 г. $2 \mathrm{~S}$, ad. Краснодарский край, 
ст-ца Калужская. С. А. Островских (ЗМ СГУ); № 230/1439-1440. 15.06.2007 г. 2 S, ad. Краснодарский край, пос. Абрау. С. А. Островских (ЗМ СГУ).

Отряд Бесхвостые земноводные -

Anura Fischer von Waldheim, 1813

Семейство Пискуньи -

Arthroleptidae Mivart, 1869

Род Пискуньи - Arthroleptis Smith, 1849

Длиннопалая пискунья - Arthroleptis stenodactylus Pfeffer, 1893.

Коллекиионный материал $(n=5)$ : № 235/ 1451. 26.12.2009 г. Центральная Африка, Республика Малави, Южная провинция, 90 км 3 г. Блантайр. В. В. Аникин (ЗМ СГУ); № 282/1638. 09.01.2011 г. S. Africa, Zimbabwe, 35 km S-E Masvingo, Kyle Recreational Park, S 20¹3'19" E $31^{\circ} 00^{\prime} 25^{\prime \prime}, \mathrm{h}=1049$ m. В. В. Аникин (ЗМ СГУ); № 289/1653-1654. 30.12.2010 г. Е. Africa, NE Zambia, $10 \mathrm{~km}$ S Isoka, S 10¹1'83" E 32 37'86", h = $=1497 \mathrm{~m}$. В. В. Аникин (ЗМ СГУ); № 367/1967. 23.12.2011 г. E. Africa, S. Malawi, Mangochi District, $25 \mathrm{~km}$ E Mangochi, Manizimu Forest Reserve, Uzuzu Hill, S $14^{\circ} 24^{\prime} 80^{\prime \prime}$ E $35^{\circ} 22^{\prime} 69^{\prime \prime}$. В. В. Аникин (ЗМСГУ).

Род Древесницы - Leptopelis Günther, 1859

Древесница жёлтопятнистая - Leptopelis flavomaculatus (Günther, 1864).

Коллекиионный материал $(n=2)$ : № 237/ 1453. 27-29.12.2008 г. Центральная Африка, Республика Малави, 90 км В г. Блантайр, горы Муланжи. В. В. Аникин (ЗМ СГУ); № 290/1655. 12.12.2010 г. E. Africa, S. Malawi, Mt. Mulanje, 96 km E Blantyre, Ruo Valley Forest, S 1558'31" E 35³9'28", h=902 m. В. В. Аникин (ЗМ СГУ).

Мозамбикская древесница - Leptopelis mossambicus Poynton, 1985.

Коллекиионный материал $(n=2)$ : № 366/ 1966. 23.12.2011 г. E. Africa, S. Malawi, Mangochi District, $25 \mathrm{~km}$ E Mangochi, Manizimu Forest Reserve, Uzuzu Hill, S $14^{\circ} 24^{\prime} 80^{\prime \prime}$ E $35^{\circ} 22^{\prime} 69^{\prime \prime}$. В. В. Аникин (ЗМ СГУ).

Семейство Жерлянки -

Bombinatoridae Gray, 1825

Род Жерлянка - Bombina Oken, 1816

Краснобрюхая жерлянка - Bombina bombina (Linnaeus, 1761).

Коллекиионный материал $(n=52)$ : № 28/ 118-122. 01.08.1994 г. 1 M., 1 F. ad. 3 S. juv. Краснодарский край, республика Адыгея, Тахтамукайский р-н, окрестности с. Старобжегокай. Т. Ю. Пес- кова (ЗМ СГУ); № 41/158-167. 28.08.1996 г. Украина, Винницкая обл., окрестности г. Винница. В. Г. Табачишин (ЗМ СГУ); № 63/437-471. 14.09.1997 г. Тамбовская обл., окрестности г. Уварово. Р. А. Романов (ЗМ СГУ); № 207/1377-1378. 25.09.2000 г. 2 S., ad. Украина, Винницкая обл., окрестности г. Винница. В. Г. Табачишин (3М СГУ).

Дальневосточная жерлянка - Bombina orientalis (Boulenger, 1890).

Коллекиионный материал $(n=1)$ : № 143/ 1133. 30.07.2005 г. Приморский край, Покровский p-н, с. Покровка (урочище Орлихи). В. В. Аникин (ЗМ СГУ).

Семейство Жабы - Bufonidae Gray, 1825 Род Amietophrynus Frost et all, 2006

Оливковая жаба - Amietophrynus garmani (Meek, 1897).

Коллекиионный материал $(n=1)$ : № 277/ 1633. 28.09.2009 г. Южно-Африканская Республика, Квазулу Наталь, окрестности г. Питермарицбург. В. В. Аникин (ЗМ СГУ).

Красноногая жаба - Amietophrynus gutturalis (Power, 1927).

Коллекиионный материал ( $n=11)$ : № 234/ 1449-1450. 26-27.01.2009 г. Южно-Африканская Республика, Наталь провинция, ферма Саньяти. В. В. Аникин (ЗМ СГУ); № 274/1630. 28.09.2009 г. Южно-Африканская Республика, Квазулу Наталь, окрестности г. Питермарицбург. В. В. Аникин (3М СГУ); № 281/1637. 02.01.2011г. Южная Африка, Замбия, Northern Zambia Prov., Mutinondo Wilderness. В. В. Аникин (ЗМ СГУ); № 296/1666. 09.01.2011 г. Южная Африка, Зимбабве, $35 \mathrm{~km} \mathrm{SE}$ Mosvingo, Kyle RP. В. В. Аникин (ЗМ СГУ); № 297/1667. 09.01.2011 г. Южная Африка, Мозамбик, Chicamba Dam, 20 km E Manica. B. B. Аникин (ЗМ СГУ); № 339/1855-1856. 04.12.2011 г. ЮжноАфриканская Республика, Квазулу Наталь, Weenen G. R. В. В. Аникин (ЗМ СГУ); № 342/1860. 16.12.2011 г. Южная Африка, Зимбабве, Manicaland Prov., Vukutu. В. В. Аникин (ЗМ СГУ); № 340/1857. 08.01.2012 г. Южная Африка, Зимбабве, $30 \mathrm{~km}$ SE Mosvingo, Mushandike Sanctuary. В. В. Аникин (ЗМ СГУ); № 364/1964. 23.12.2011 г. E. Africa, S. Malawi, Mangochi District, $25 \mathrm{~km} \mathrm{E}$ Mangochi, Manizimu Forest Reserve, Uzuzu Hill, S $14^{\circ} 24^{\prime} 80^{\prime \prime}$ E $35^{\circ} 22^{\prime} 69^{\prime \prime}$. В. В. Аникин (ЗМ СГУ).

Длинноногая жаба - Amietophrynus kisoloensis (Loveridge, 1932).

Коллекиионный материал $(n=3)$ : № 280/ 1636. 17.12.2010 г. Республика Малави, окрестности г. Нчиси. В. В. Аникин. (ЗМ СГУ); № 288/1652. 29.12.2010 г. Республика Малави, окрестности 
г. Читипа. В. В. Аникин (ЗМ СГУ); № 292/1658. Малави, Mangochi Manizimu FR, Uzuzu Hill. В. В. Аникин (ЗМ СГУ),

Пятнистая жаба - Amietophrynus maculatus (Hallowell, 1854).

Коллекиионный материал $(n=1)$ : № 365/ 1965. 18.11.2011 г. Гана, 30 км N г. Кейп-Кост, Hans Cottege Botel. В. В. Аникин (ЗМ СГУ).

Amietophrynus poweri (Hewitt, 1935).

Коллекиионный материал $(n=1)$ : № 201/

1349. 01.01.2008 г. 1 S. јuv. Южно-Африканская Республика, Провинция Фри Стейт, 20 км 3 г. Винбург. В. В. Аникин (ЗМ СГУ). witt, 1935)

Хриплая жаба - Amietophrynus rangeri (He-

Коллекиионный материал $(n=1)$ : № 273/ 1629. 04.10.2009 г. Южно-Африканская Республика, Провинция Северный Кейп, окрестности г. Спрингбок. В. В. Аникин (ЗМ СГУ).

\section{Род Жаба - Bufo Laurenti, 1768}

Серая или обыкновенная жаба - Bufo bufo (Linnaeus, 1758).

Коллекиионный материал (n=10): № 18/5758. 21.07.1990 г. Новосибирская обл., Чановский p-н, окрестности пос. Озеро-Карачи. Ю. С. Равкин (ЗМ СГУ); № 19/59-60.31.07.1990 г. Томская обл., Чаинский р-н, окрестности пос. Коломино. Ю. С. Равкин (ЗМ СГУ); № 93/711. 24.12.1999 г. Томская обл., Кожевниковский р-н, окрестности с. Киреевск. В. Н. Куранова (ЗМ СГУ); № 196/ 1258-1259. 21.08.2007 г. Республика Мордовия, Большеигнатовский р-н, окрестности пос. Лесной (НП «Смольный»). А. Б. Ручин (ЗМ СГУ); №216/ 1400-1402. 05.05.2008 г. Республика Мордовия, Темниковский р-н, 6 км С3 пос. Пушта (оз. Инорское, Мордовский заповедник). А. Б. Ручин (3М СГУ).

Зелёная жаба - Bufo viridis Laurenti, 1768.

Коллекиионный материал $(n=52)$ : № 57/ 372. 26.08.1997 г. Белгородская обл., окрестности г. Новый Оскол. Т. А. Якушева (ЗМ СГУ); № 59/ 377- 401. 28.08.1997 г. Астраханская обл., Приволжский р-н, 20 км южнее г. Астрахань. Е. В. Завьялов (ЗМ СГУ); № 65/487. 14.09.1997 г. Тамбовская обл., окрестности г. Уварово. Р. А. Романов (ЗМ СГУ); № 72/525-527. 05.05.1998 г. Астраханская обл., Красноярский р-н, окрестности пос. Досанг. В. В. Аникин (ЗМ СГУ); № 73/528-530. 08.05.1998 г. Астраханская обл., Красноярский p-н, окрестности пос. Молодежный. В. В. Аникин (ЗМ СГУ); № 74/531. 09.05.1998 г. Астраханская обл., Красноярский р-н, окрестности пос. Степной. В. В. Аникин (ЗМ СГУ); № 81/565-568.
15.08.1998 г. Украина, Винницкая обл., окрестности г. Винница. В. Г. Табачишин (ЗМ СГУ); № 110/949-954. 15.05.2001 г. Ставропольский край, г. Минеральные воды. Н. Н. Якушев (ЗМ СГУ); № 103/881-884. 10.08.2002 г. Республика Казахстан, Западно-Казахстанская обл., оз. Шалкар. В. В. Аникин (ЗМ СГУ); № 122/1081-1087. 07.07.2003 г. УКраина, Крым, Бахчисарайский р-н, окрестности пос. Соколиное. В. Г. Табачишин (ЗМ СГУ); № 130/1107. 24.05.2005 г. Республика Калмыкия, Сарпинский р-н, пос. Годжур. В. В. Аникин (ЗМ СГУ); № 153/1148. 08.05.2006 г. Краснодарский край, Администрация г. Геленжик, окрестности пос. Кабардинка. В. В. Аникин (3М СГУ); № 183/1225. 02.05.2007 г. Волгоградская обл., Старополтавский р-н, окрестности с. Нов. Квасниковка (берег р. Еруслан). Е. В. Семенушкина (ЗМ СГУ); № 194/1252-1256. 12.08.2007 г. Кабардино-Балкарская Республика, Эльбрусский p-н, окрестности пос. Эльбрус (ущелье Адыл Су, 2700 м). М. В. Ермохин, И. В. Прядилова (3М СГУ); № 226/1432. 25.09.2007 г. 1 М. Краснодарский край, г. Краснодар. С. А. Островских (3М СГУ); № 212/1390-1391. 16.14.2008 г. 1 F ad, 1 M ad. Республика Казахстан, Южно-Казахстанская обл., Сузакский р-н, С3 65 км пос. Жуантобе. В. Г. Табачишин (ЗМ СГУ); № 220/1421-1422. 06.07.2008 г. Киргизская Республика, Ошская обл., Чон-Алайский р-н, 20 км Ю3 пос. Дароот-Каргон. В. В. Аникин (ЗМ СГУ); № 222/1424. Киргизская Республика. В. В. Аникин (ЗМ СГУ); № 243/1481. 31.07.2009 г. Самарская обл., окрестности с. Жигули. В. В. Аникин (ЗМ СГУ); № 361/1961. 21.09.2013 г. Астраханская обл., Ахтубинский р-н, оз. Карасун. А. С. Айряпетян (ЗМ СГУ); № 362/ 1962. 21.09.2013 г. Астраханская обл., Ахтубинский р-н, р. Горькая. А. С. Айряпетян (ЗМ СГУ).

Кавказская жаба - Bufo verrucosissimus (Pallas, [1814]).

Коллекиионный материал $(n=3)$ : № $129 /$ 1105-1106. 20.07.2004 г. Краснодарский край, Апшеронский р-н, окрестности пос. Мезмай. С. А. Островских (ЗМ СГУ); № 192/1250. 14.07.2007 г. Краснодарский край, Администрация г. Геленджик, окрестности пос. Кабардинка. Е. В. Завьялов (ЗМ СГУ).

Дальневосточная жаба - Bufo gargarizans Cantor, 1842.

Коллекиионный материал $(n=5)$ : № 141/ 1129-1130. 17.07.2005 г. Еврейская АО, Облученский р-н, 3 км В пос. Радде. В. В. Аникин (ЗМ СГУ); № 144/1134. 04.08.2005 г. Приморский край, Славянский р-н, окрестности с. Занадворовка. В. В. Аникин (ЗМ СГУ); № 331/1813-1814. 05.08.2012 г. о-в Сахалин, окрестности г. Ю. Са- 
халинск (гора Большевик). Е. Ю. Мосолова (ЗМ СГУ).

Монгольская жаба - Bufo raddei Strauch, 1876.

Коллекиионный материал $(n=3)$ : № $137 /$ 1125. 08.07.2005 г. Еврейская АО, Ленинский р-н, окрестности пос. Ленинское (р. Солнечная). В. В. Аникин (ЗМ СГУ); № 167/1193. 24.07.2006 г. Агинский Бурятский автономный округ, Агинский р-н, оз. Холанда. В. В. Аникин (ЗМ СГУ); № 267/1607. 03.07.2010 г. Монголия, Ховдский аймак, бассейн р. Бодончин-Гол. В. В. Аникин (3М СГУ).

\section{Род Красные жабы - Schismaderma Smith, 1849 \\ Красная жаба - Schismaderma carens (Smith,} 1848).

Коллекиионный материал $(n=5)$ : № 236/ 1452. 04.01.2009 г. Малави, заповедник Нкотакота. В. В. Аникин (ЗМ СГУ); № 271/1627. 27.09.2009 г. Южно-Африканская Республика, Квазулу Наталь провинция, окрестности г. Питермарицбург. В. В. Аникин (ЗМ СГУ); № 275/1631. 28.09.2009 г. Южно-Африканская Республика, Квазулу Наталь провинция, окрестности г. Питермарицбург. В. В. Аникин (ЗМ СГУ); № 320/1765. 12.12.2011 г. Южно-Африканская Республика, Лимпопо провинция, 50 км NW Mokopane Waterberg Wildness Reserve. В. В. Аникин (ЗМ СГУ); № 338/ 1854. 04.12.2011 г. Южно-Африканская Республика, Квазулу Наталь, Weenen G. R. B. B. Аникин (ЗМ СГУ).

Род Vandijkophrynus Laurenti, 1768

Vandijkophrynus robinsoni Branch and Braack, 1996.

Коллекиионный материал ( $n=7)$ : № 202/ 1350-1355. 13.01.2008 г. Южно-Африканская Республика, Северный Кейп провинция, 40 км Ю3 г. Спрингбок. В. В. Аникин (ЗМ СГУ); № 278/ 1634. 04.10.2009 г. Южно-Африканская Республика, Северный Кейп провинция, 80 км ЮЗ г. Спринбок. В. В Аникин (ЗМ СГУ).

Семейство Квакши - Hylidae Rafinesque, 1815 Род Квакша - Hyla Laurenti, 1768 naeus, 1758).

Обыкновенная квакша - Hyla arborea (Lin-

Коллекиионный материал $(n=6)$ : № 31/ 125-126. 20.06.1996 г. Краснодарский край, Республика Адыгея, Майкопский р-н, окрестности пос. Никель (пойма р. Белая). Г. Б. Бахтадзе (3М СГУ); № 56/370-371. 19.08.1997 г. Украина, Винницкая обл., Винницкий р-н, окрестности с. Зарванцы. В. Г. Табачишин (ЗМ СГУ); № 69/506.
04.10.1997 г. Украина, Винницкая обл., окрестности г. Винница (опушка буково-грабовой дубравы). В. Г. Табачишин (ЗМ СГУ); № 115/1002. 22.07.2001 г. Украина, АР Крым, окрестности г. Севастополь. Ю. В. Кармышев (ЗМ СГУ).

Семейство Прыгуньи - Hyperolidae Laurent, 1943 Род Тростянка - Hyperolius Rapp, 1842

Разноцветная тростянка - Hyperolius marmoratus Linnaeus, 1758.

Коллекиионный материал ( $n=13)$ : № 209/ 1383. 23-25.01.2008 $1 \mathrm{~S}$ juv. Южно-Африканская Республика, Квазулу Наталь провинция, Vernon Crookes N.R. 60 км SW г. Дурбан. В. В. Аникин (ЗМ СГУ). № 233/1448. 25.01.2009 г. ЮжноАфриканская Республика, Наталь провинция, 45 км ЮВ г. Понгола. В. В. Аникин (ЗМ СГУ); № 272/ 1628. 27.09.2009 г. Южно-Африканская Республика, Квазулу Наталь провинция, окрестности г. Питермарицбург. В.В.Аникин (ЗМ СГУ); № 276/1632. 28.09.2009 г. Южно-Африканская Республика, Квазулу Наталь провинция, окрестности г. Питермарицбург. В. В. Аникин (ЗМ СГУ); № 287/1645-1651. 03.12.2010 г. Зимбабве, Маникаленд провинция, Vukutu. В. В. Аникин (3М СГУ); № 343/1861-1862. 16.12.2011 г. Зимбабве, Мани-календ провинция, Vukutu. В. В. Аникин (ЗМ СГУ). Ahl, 1931.

Скрипучая тростянка - Hyperolius kivuensis

Коллекиионный материал $(n=5)$ : № 285/ 1643. 31.12.2010 г. Замбия, окрестности г. Макупула, Капишя Хот Спрингс Лодж. В. В. Аникин (ЗМ СГУ); № 295/1664-1665. 24.12.2010 г. Малави, Округ Румпи, Национальный парк Nyika. В. В. Аникин (ЗМ СГУ); № 298/1668-1669. 08.12.2010 г. Мозамбик, Chicamba Dam, 20 км E г. Маника. В. В. Аникин (ЗМ СГУ). ters, 1854

Золотистая тростянка - Hyperolius argus Pe-

Коллекционный материал $(n=3)$ : № 283/ 1639-1641. 10.12.2010 г. Мозамбик, 8 км Е Каия (Cuacua Lodge), р. Замбези. В. В. Аникин (3М СГУ).

Окаймленная тростянка - Hyperolius puncticulatus (Pfeffer, 1893).

Коллекиионный материал $(n=1)$ : № 286/ 1644. 12.12.2010 г. Малави, 96 км Е г. Блантайр (горный массив Муландже). В. В. Аникин (3М СГУ).

Род Кассина - Kassina Girard, 1853

Сенегальская кассина - Kassina senegalensis (Duméril et Bibron, 1841). 
Коллекиионный материал $(n=1)$ : № 270/ 1626. 27.09.2009 г. Южно-Африканская Республика, Квазулу Наталь провинция, окрестности г. Питермарицбург. В. В. Аникин (ЗМ СГУ).

Семейство Чесночницы -

Pelobatidae Bonaparte, 1850

Род Чесночница - Pelobates Wagler, 1830

Обыкновенная чесночница - Pelobates fuscus (Laurenti, 1768).

Коллекиионный материал $(n=29)$ : № 27/ 116-117. 01.06.1992 г. 1 M. ad. 1 S. juv. Краснодарский край, Приморско-Ахтарский р-н, с. Садки. Т. Ю. Пескова (ЗМ СГУ); № 64/472-486. 14.09.1997 г. Тамбовская обл., окрестности г. Уварово. Р. А. Романов (ЗМ СГУ); № 75/532-541. 09.05.1998 г. Астраханская обл., Красноярский p-н, окрестности пос. Степной. В. В. Аникин (3М СГУ); № 193/1250-1251. 04.08.2007 г. Нижегородская обл., Навашинский р-н, с. Покров (р. Теша). А. Б. Ручин (ЗМ СГУ); № 363/1963. 23.09.2013 г. Астраханская обл., Ахтубинский р-н, подножье горы Богдо. А. С. Айряпетян (ЗМ СГУ).

Семейство Крестовки -

Pelodytidae Bonaparte, 1850

Род Крестовки - Pelodytes Bonaparte, 1838

Кавказская крестовка - Pelobates caucasicus (Laurenti, 1768).

Коллекиионный материал $(n=1)$ : № 315/ 1754. 03.08.2011 г. Краснодарский край, Апшеронский р-н, пос. Мезмай. М. В. Ермохин (3М СГУ).

Семейство Пиповые - Pipidae Gray, 1825

Род Шпорцевые лягушки Xenopus Wagler, 1827

Гладкая шпорцевая лягушка - Xenopus laevis (Daudik, 1802).

Коллекиионный материал $(n=2)$ : № 332/18151816. 20.12.2011 г. Мозамбик, 8 км Е Каия (р. Замбези). В. В. Аникин (ЗМ СГУ).

Семейство Pyхicephalidae Bonaparte, 1850 Род - Amietia Dubois, 1987 (Bocage, 1866).

Ангольская лягушка - Amietia angolensis

Коллекиионный материал $(n=3)$ : № 284/ 1642. 09.01.2011 г. Zimbabwe, 35 км S-E Masvingo, Kyle Recreational Park, S $20^{\circ} 13^{\prime} 19^{\prime \prime}$ E $31^{\circ} 00^{\prime} 25^{\prime \prime}, \mathrm{h}=$ 1049 м (Лимпопо). В. В. Аникин (ЗМ СГУ); № 368/1968-1969. 23.12.2011 г. E.Africa, S Malawi, Mangochi Manizimu FR, Uzuzu Hill. B. В. Аникин (ЗМСГУ).
Род - Pухісерhalus Tschudi, 1838

Водонос съедобный - Pyxicephalus edulis Peters, 1854.

Коллекиионный материал ( $n=1)$ : № 279/ 1635. 09.12.2010 г. Мозамбик, 8 км Е г. Каия, Cuacua Lodge, p. Замбези (S 17²4'91" Е 35²4'72"), $h=39$ м. В. В. Аникин (ЗМ СГУ).

Семейство Лягушки - Ranidae Rafinesque, 1814 Род Зелёная (водная) лягушка Pelophylax Fitzinger, 1843 Pallas, 1771

Озёрная лягушка - Pelophylax ridibundus

Коллекционный материал $(n=56)$ : № 49 /335-338. 24.06.1997 г. Ростовская обл., окрестности г. Каменск-Шахтинский. В. Г. Табачишин (ЗМ СГУ); №77/550. 10.05.1998 г. Астраханская обл., Красноярский р-н, окрестности пос. Малый Арал. Е. В. Завьялов (ЗМ СГУ). № 78/551-560. 15.07.1998 г. Воронежская обл., окрестности г. Богучар (пойма р. Дон). В. Г. Табачишин (ЗМ СГУ); № 86/617-624. 27.07.1999 г. Белгородская обл., окрестности г. Новый Оскол (пойма р. Беленькая). Т. А. Якушева (ЗМ СГУ); № 121/1077-1080. 06.07.2003 г. Украина, АР Крым, Бахчисарайский p-н, окрестности пос. Соколиное (р. Кокозка). Е. В. Завьялов (ЗМ СГУ); № 124/1090-1098. 25.09.2003 г. Грузия, АР Абхазия, окрестности г. Гагры. Е. В. Завьялов (ЗМ СГУ); № 128/1104. 07.07.2004 г. Украина, АР Крым, Бахчисарайский p-н, окрестности пос. Соколиное (р. Кокозка). В. В. Аникин (ЗМ СГУ); № 135/1122. 06.07.2005 г. Украина, АР Крым, Бахчисарайский р-н, окрестности с. Терновка. Е. В. Завьялов (ЗМ СГУ); № 154/1149-1150. 09.05.2006 г. Краснодарский край, Администрация г. Геленджик, окрестности пос. Кабардинка. В. Г. Табачишин (ЗМ СГУ); № 165/1185. 10.07.2006 г. Краснодарский край, Администрация г. Геленджик, окрестности пос. Кабардинка. В. В. Аникин (ЗМ СГУ); № 171/11971198. 23.08.2006 г. Астраханская обл., окрестности с. Болхуны. К. А. Сонин (ЗМ СГУ); № 182/1224. 01.05.2007 г. Ростовская обл., окрестности г. Белая Калитва (пойма р. Белая Калитва). Э. И. Кайбелева (ЗМ СГУ); № 184/1226. 03.05.2007 г. КарачаевоЧеркесская Республика, Карачаевский р-н, пос. Домбай. Е. В. Завьялов (ЗМ СГУ); № 211/ 1388-1389. 03.05.2007 г. Карачаево-Черкесская Республика, Карачаевский p-н, пос. Домбай. Е. В. Завьялов (ЗМ СГУ); № 221/1423.03.07.2008 г. Киргизская Республика, Жалал-Абадская обл., Токтогульский p-н, 11 км Ю3 г. Кара-Кёл. В. В. Аникин (ЗМ СГУ); № 262/1596. 25.05.2009 г. АР Абхазия, Гагрский р-н, оз. Рица. В. В. Аникин (3М 
СГУ); № 264/1598-1603. 06.08.2010 г. Республика Калмыкия, Юстинкский р-н, окрестности пос. Цаган-Аман (остров Песчаный). А. А. Горяев (3М СГУ); № 334/1816. 14.09.2012 г. Волгоградская обл., Иловлинский р-н, хут. Б. Колдаиров (р. Дон). Е. Ю. Мосолова (ЗМ СГУ).

Прудовая лягушка - Pelophylax lessonae (Lichtenstein, 1823).

Коллекиионный материал ( $n=5)$ : №79/561. 15.08.1998 г. Украина, Винницкая обл., окрестности г. Винница. В. Г. Табачишин (ЗМ СГУ); № 208/ 1379-1382. 25.09.2000 г. 1 S., sad., 3 S., juv. Украина, Винницкая обл., окрестности г. Винница. В. Г. Табачишин (ЗМ СГУ).

Съедобная лягушка - Pelophylax esculenta (Lichtenstein, 1823).

Коллекиионный материал $(n=3)$ : № $187 /$ 1240-1241. 21.05.2007 г. Республика Мордовия, Большеигнатовский р-н, окрестности пос. Лесной (НП «Смольный»). А. Б. Ручин (ЗМ СГУ); № 204/ 1357. 07.05.2008 г. 1 М. Республика Мордовия, Ичалковский р-н, пос. Обрезки (пруд). А. Б. Ручин (ЗМ СГУ).

Чернопятнистая лягушка -Pelophylax nigromaculata Hallowell, 1860.

Коллекиионный материал $(n=2)$ : № $136 /$ 1123-1124. 08.07.2005 г. Еврейская АО, Ленинский р-н, окрестности пос. Ленинское (р. Солнечная). В. В. Аникин (ЗМ СГУ).

Род Бурая (травяная) лягушка Rana Linnaeus, 1758

Сибирская лягушка - Rana amurensis Boulenger, 1886.

Коллекиионный материал $(n=2)$ : № 95/ 713-714. 24.12.1999 г. Томская обл., Кожевниковский р-н, окрестности с. Киреевск. В. Н. Куранова (ЗМ СГУ). son, 1842.

Остромордая лягушка - Rana arvalis Nils-

Коллекиионный материал ( $n=19)$ : № 198/ 1267. 15.08.1996 г. Самарская обл., окрестности г. Жигулевск. ? (ЗМ СГУ); № 62/420-436. 14.09.1997 г. Тамбовская обл., окрестности г. Уварово. Р. А. Романов (ЗМ СГУ); № 94/712. 24.12.1999 г. Томская обл., Кожевниковский р-н, окрестности с. Киреевск. В. Н. Куранова (3М СГУ). parte, 1840.

Прыткая лягушка - Rana dalmatina Bona-

Коллекционный материал $(n=5)$ : № 190/ 1246-1248. 25.06.2007 г. Украина, Черновицкая обл., Новоселицкий р-н, окрестности с. Черновка. Н. А. Смирнов (ЗМ СГУ); № 354/1942-1943. 01.08.2013 г. Болгария, Кюстендинская обл., НП
«Рыльский монастырь» (Кирилова поляна). В. В. Аникин (ЗМ СГУ).

Дальневосточная лягушка - Rana dybowskii Gunter, 1876. Коллекиионный материал $(n=1)$ : № 140/ 1128. 13.07.2005 г. Еврейская АО, Облученский p-н, верховье р. Биджан. В. В. Аникин (ЗМ СГУ).

Малоазиатская лягушка - Rana macrocnemis Boulenger, 1885.

Коллекиионный материал $(n=29)$ : № 30/ 124. 17.06.1996 г. Краснодарский край, Республика Адыгея, Майкопский р-н, окрестности пос. Никель (пойма р. Белая). Г. Б. Бахтадзе (3М СГУ); № 123/1088- 1089. 08.08.2003 г. КабардиноБалкарская Республика, Эльбрусский р-н, пойма p. Адырсу $(h=2400$ м). В. В. Аникин (ЗМ СГУ); № 185/1227-1229. 03.05.2007 г. Карачаево-Черкесская Республика, Карачаевский р-н, пос. Домбай. Е. В. Завьялов (ЗМ СГУ); № 186/1230-1239. 05.05.2007 г. Карачаево-Черкесская Республика, Карачаевский р-н, пос. Домбай. А. К. Суркина (3М СГУ); № 195/1257. 12.08.2007 г. Республика Кабардино-Балкария, Эльбрусский р-н, окрестности пос. Эльбрус (ущелье Адыл Су, 2700 м). М. В. Ермохин, И. В. Прядилова (ЗМ СГУ); № 210/ 1384-1387. 03.05.2007 г. Карачаево-Черкесская Республика, Карачаевский р-н, Тебердинский заповедник. Е. В. Завьялов (ЗМ СГУ); №229/ 1437-1438. 18.07.2007 г. 2 S, ad. Краснодарский край, Апшеронский р-н, пос. Камышанов (Биостанция «Камышанова поляна»). С. А. Островских (ЗМ СГУ); № 266/1606. 23.08.2010 г. Карачаево-Черкесская Республика, Малокарачаевский p-н, долина р. Джамагат. О. А. Помазенко (3М СГУ); № 293/1659-1661. 03.05.2011 г. КарачаевоЧеркесская р-ка, Малокарачаевский р-н, пос. Домбай. В. В. Аникин (ЗМ СГУ); № 323/1768-1769. 03.05.2012 г. Карачаево-Черкесская Республика, Малокарачаевский р-н, пос. Домбай. Е. Ю. Мосолова (ЗМСГУ). naeus, 1758 .

Травяная лягушка - Rana temporaria Lin-

Коллекиионный материал $(n=20)$ : № 42/ 168. 28.08.1996 г. Украина, Винницкая обл., Винницкий р-н, окрестности с. Сосонка. В. Г. Табачишин (ЗМ СГУ); № 55/369. 12.08.1997 г. Алтайский край, Тогульский район, окрестности с. Бол. Топтушка. О. В. Рубцова (ЗМ СГУ); № 58/373376. 26.08.1997. Белгородская обл., окрестности г. Новый Оскол. Т. А. Якушева (ЗМ СГУ); № 68/500-505. 04.10.1997 г. 1 M. ad. 5 S. sad. Украина, Винницкая обл., окрестности г. Винница. В. Г. Табачишин (ЗМ СГУ); № 170/1196. 15.08.2006 г. Мурманская обл., Администрация г. Апатиты, окрестности пос. Хибины. В. В. Ани- 
кин (ЗМ СГУ); № 299/1670. 15.06.2011 г. Дания, Ютландия, 30 км ЮВ г. Скиве, пос. Стохольм (N $56^{\circ} 28^{\prime} 78^{\prime \prime}$ Е 905'39"). В. В. Аникин (ЗМ СГУ); № 356/1947-1949. 15.07.2013 г. Ленинградская обл., Ломоносовский р-н, окрестности д. СистоПалкино (берег Финского залива, смешанный лес). Д. С. Галушко (ЗМ СГУ); № 355/1944-1946. 18.08.2013 г. Ленинградская обл., окрестности г. Кронштадт. Т. В. Перевозникова (ЗМ СГУ).

\section{Семейство Веслоногие лягушки - Rhacophorinae, Hoffman, 1932 \\ Род Хватающие лягушки - \\ Chiromantis Peters, 1854}

Chiromantis xerampelina Peters, 1854.

Коллекиионный материал $(n=4)$ : № 291/ 1656-1657. 14.12.2010 г. Малави, Округ Мангоче, 25 км Е г. Мангоче (Manizimu Forest Reserve, Uzuzu Hill), S 1424'80" E 35²2'69", h = 1135 м. В. В. Аникин (ЗМ СГУ); № 341/1858-1859. 24.12.2011 г. Малави, Округ Мангоче, 2 5км Е г. Мангоче (Manizimu Forest Reserve). В. В. Аникин (ЗМ СГУ).

\section{АНАЛИЗ СОВРЕМЕННОГО СОСТОЯНИЯ БАТРАХОЛОГИЧЕСКОЙ КОЛЛЕКЦИИ ЗООЛОГИЧЕСКОГО МУЗЕЯ САРАТОВСКОГО УНИВЕРСИТЕТА}

География научных колекционных хранилищ, содержащих сборы с территории Саратовской области, не широка. На сегодняшний день выявлено 4 естественнонаучных музея, где представлены материалы по амфибиям региона (табл. 1). Наибольшее количество единиц хранения по количеству видов и особей учтено в фондах Зоологического музея Саратовского университета.

В настоящее время (по состоянию на декабрь 2018 г.) батрахологическая коллекция Зоологического музея СГУ насчитывает 1903 экз. амфибий, относящихся к 46 видам 13 семействам.

Таблица 1. Объем коллекционных сборов по Саратовской области, хранящихся в зоологических музеях России и зарубежья

Table 1. Volume of the collections made in the Saratov region and stored in all zoological museums in Russia and abroad

\begin{tabular}{c|l|c|c}
\hline \multirow{2}{*}{$\begin{array}{c}\text { № } \\
\text { п/п }\end{array}$} & \multicolumn{1}{|c|}{ Наименование музея } & \multicolumn{2}{|c}{ Количество } \\
\cline { 3 - 4 } & & видов & особей \\
\hline 1 & 3М СГУ (г. Саратов) & 6 & 1447 \\
\hline 2 & ЗИН РАН (г. Санкт-Петербург) & 6 & 131 \\
\hline 3 & ЗМ ННПМ НАНУ (г. Киев) & 2 & 19 \\
\hline 4 & ИЭВБ РАН (г. Тольятти) & 3 & 9
\end{tabular}

Наиболее полно в видовом отношении в коллекции представлено семейство лягушек, занимающее в ней $43.3 \%$ от общего числа единиц хранения. Фонды содержат 711 экземпляров 10 видов лягушек, из которых на долю саратовских сборов приходится 2 вида (569 экземпляра). Относительно богаты серии жерлянок и жаб, которые по числу особей составляют 18.2 и $17.9 \%$ от всего объема коллекции соответственно (табл. 2).

По большинству представителей этих семейств имеются обширные сборы, о чем свидетельствуют относительно высокие показатели среднего количества экземпляров на вид в пределах указанных таксонов. Наиболее высок этот показатель для чесночниц (в среднем 200 экз./ вид) и жерлянок (130). Имеются богатые сборы по отдельным видам: у краснобрюхой жерлянки (Bombina bombina L., 1761), чесночницы обыкновенной (Pelobates fuscus (Laurenti, 1768)) и остромордой лягушки (Rana arvalis N., 1842.) отдельные выборки насчитывают до 100 и более экземпляров. В наименьшей степени в коллекции представлены хвостатые амфибии (углозубы - менее $0.3 \%$ ), а также квакши (около $0.4 \%$ ).

Около $80 \%$ коллекции составляют взрослые земноводные, среди которых соотношение полов почти равное. Особенно хорошо это проявляется в сборах лягушек, жаб и саламандровых, что обусловлено выборочным сбором амфибий в весенний период, когда половой диморфизм у амфибий ярко выражен. Наличие небольшого числа взрослых земноводных, для которых пол не был точно определен, обусловлено трудностями дифференциации мелких животных при слабой выраженности половых признаков (например, у жерлянок и квакш). Молодые животные первого и второго годов жизни составляют значительную часть сборов только у жаб и жерлянок.

Не меньший интерес при каталогизации представляет анализ географии сборов. В коллекции Зоологического музея СГУ представлены все виды региональной батрахофауны, а также 21 вид из фаунистических комплексов других регионов, в том числе Поволжья, Северного Кавказа, Сибири, Дальнего Востока, Средней Азии, Восточной Европы, Крыма и Африканского континента. Более половины региональных сборов приурочено к долинам рек Хопра, Медведицы, Волги и Еруслана. Имеются выборки практически из всех физикогеографических районов области, но доля сборов по каждому из них, за исключением вышеуказанных, не превышает 5\%. В наибольшей степени по числу видов представлены Волго-Терешкинский, Идолго-Медведицкий районы, а также Волжский террасовый центральный. По количеству единиц 
Таблица 2. Таксономическая характеристика коллекционных сборов амфибий, хранящихся в Зоологическом музее Саратовского университета (по состоянию на декабрь 2018 г.)

Table 2. Taxonomic characteristics of the amphibian collections stored in the Zoological Museum of the Saratov State University (as of December 2018)

\begin{tabular}{|c|c|c|c|c|}
\hline \multirow[b]{2}{*}{ Отряд / семейство } & \multirow[b]{2}{*}{ Число видов } & \multicolumn{3}{|c|}{ Количество экземпляров } \\
\hline & & $\begin{array}{c}\text { Саратовская } \\
\text { область }\end{array}$ & Другие регионы & Всего \\
\hline Хвостатые - Caudata & 6 & 28 & 60 & 88 \\
\hline Углозубы (Hynobiidae) & 1 & - & 4 & 4 \\
\hline Саламандровые (Salamandridae) & 5 & 28 & 56 & 84 \\
\hline Бесхвостые - Anura & 40 & 1413 & 395 & 1808 \\
\hline Жерлянки (Bombinatoridae) & 2 & 237 & 53 & 290 \\
\hline Чесночницы (Pelobatidae) & 1 & 406 & 30 & 436 \\
\hline Квакши (Hylidae) & 1 & - & 6 & 6 \\
\hline Жабы (Bufonidae) & 13 & 207 & 124 & 331 \\
\hline Лягушки (Ranidae) & 10 & 569 & 142 & 709 \\
\hline Пискуньи (Arthroleptidae) & 3 & - & 8 & 8 \\
\hline Прыгуньи (Hyperolidae) & 5 & - & 23 & 23 \\
\hline Веслоногие лягушки (Rhacophorinae) & 1 & - & 4 & 4 \\
\hline Крестовки (Pelodytidae) & 1 & - & 1 & 1 \\
\hline Пиповые (Pipidae) & 1 & - & 2 & 2 \\
\hline Pyxicephalidae & 2 & - & 3 & 3 \\
\hline Всего & 46 & 1447 & 456 & 1903 \\
\hline
\end{tabular}

хранения максимальные показатели относятся к Карай-Хоперскому и Еруслано-Бизюкскому районам (табл. 3).

Не менее информативным оказывается и анализ временной приуроченности батрахологических сборов. Значительное количество видов региональной фауны, представленных в коллекции Зоологического музея СГУ, было изъято из природы в период с мая по сентябрь, тогда как наименьшая интенсивность сборов характерна для марта - апреля и октября (рис. 7). Аналогичная картина выявляется и при анализе хронологического ряда (в пределах месяцев) батрахологических научных сборов в отношении числа особей. Коллекционные экземпляры, отобранные в позднее осеннее время и зимние месяцы, в анализируемых фондах отсутствуют.

Динамика интенсивности сборов довольно тесно связана с биологическими циклами амфибий и погодными условиями, в частности с температурой окружающей среды. Так, пик сборов приходится на май, когда большинство местных амфибий приступают к размножению. В это время земноводные, ведущие скрытый образ жизни (саламандровые), легко обнаруживаются в нерестовых водоемах. К этому же времени, как правило, приурочено большинство экспедиционных работ сотрудников биологического факультета, в период которых и собирается большая часть батрахологического материала. Второй хорошо выраженный пик увеличения интенсивности сборов отме- чается в августе - сентябре, т. е. в период перед погружением животных в оцепенение. В это время коллекционные фонды пополняются в ходе непродолжительных осенних экспедиционных выездов преимущественно за счет сеголеток и молодых особей, часто совершающих массовые миграции в поисках мест зимовок. Меньшее количество батрахологического материала для научной коллекции добывается в ранневесенний и осенний периоды. В коллекции имеются 2 экземпляра зелёной жабы, поступившие в фонды Зоологического музея в феврале и пойманные в жилых строениях в г. Саратов. В холодное время года пополнение музейной коллекции происходит в основном за счет обмена фондами с другими зоологическими музеями страны и зарубежья.

Следует отметить, что относительно ранние сборы (первая половина прошлого века), вследствие совокупности объективных и субъективных причин, занимают в коллекции музея незначительную долю. Фонды начали интенсивно пополняться лишь с созданием на кафедре морфологии и экологии животных биологического факультета в середине 1980-х гг. герпетологического направления научных исследований. Так, анализ временной интенсивности батрахологических сборов в пределах последних десятилетий позволяет выявить два наиболее значимых пика, приходящихся на конец 1980-х - начало 1990-х гг, а также на конец 1990-х - начало 2000-х гг., когда в основном и была собрана большая часть коллекции. 
Таблица 3. География батрахологических сборов по Саратовской области, хранящихся в фондах зоологических музеев России и Зарубежья

Table 3. Geography of bathrachological collections in the Saratov region, stored in the funds of all zoological museums in Russia and abroad

\begin{tabular}{|c|c|c|c|c|c|}
\hline \multirow{3}{*}{$\begin{array}{c}\text { № } \\
\text { p-на }\end{array}$} & \multirow{3}{*}{ Физико-географический район, местность } & \multicolumn{4}{|c|}{ Количество } \\
\hline & & \multirow{2}{*}{ семейств } & \multirow{2}{*}{ видов } & \multicolumn{2}{|c|}{ экземпляров } \\
\hline & & & & aбc. & $\%$ \\
\hline 2 & Карай-Хоперский & 2 & 2 & 252 & 15.8 \\
\hline 3 & Изнаир-Аркадакский & 2 & 3 & 52 & 3.3 \\
\hline 5 & Елано-Альшанский & 2 & 2 & 3 & 0.2 \\
\hline 6 & Уза-Алайский & 2 & 2 & 3 & 0.2 \\
\hline 8 & Волго-Терешкинский & 5 & 6 & 94 & 5.7 \\
\hline 9 & Хоперско-Терсинский & 4 & 5 & 28 & 1.8 \\
\hline 12 & Идолго-Медведицкий & 5 & 5 & 153 & 9.6 \\
\hline 14 & Средне-Терешкинский & 3 & 4 & 23 & 1.4 \\
\hline 15 & Нижне-Терешкинский & 2 & 3 & 14 & 0.9 \\
\hline 16 & Чардымо-Курдюмский & 2 & 2 & 46 & 2.9 \\
\hline 18 & Волго-Карамышский & 4 & 4 & 70 & 4.4 \\
\hline 21 & Сестра-Камеликский & 2 & 2 & 9 & 0.6 \\
\hline 22 & Волжский террасовый центральный & 4 & 4 & 128 & 8.0 \\
\hline 23 & Караманский & 2 & 3 & 26 & 1.6 \\
\hline 24 & Верхне-Узенский & 3 & 4 & 51 & 3.2 \\
\hline 27 & Еруслано-Бизюкский & 4 & 5 & 273 & 17.1 \\
\hline 29 & Больше-Узенский & 1 & 2 & 8 & 0.5 \\
\hline 32 & Приузенский & 2 & 2 & 19 & 1.2 \\
\hline \multirow[t]{12}{*}{33} & Острова р. Волги & 1 & 2 & 14 & 0.8 \\
\hline & Долина р. Нахой & 1 & 1 & 50 & 3.1 \\
\hline & Долина р. Хопер & 3 & 4 & 82 & 5.1 \\
\hline & Долина р. Медведица & 5 & 6 & 48 & 3.0 \\
\hline & Долина р. Большой Иргиз & 4 & 5 & 53 & 3.3 \\
\hline & Долина р. Терса & 1 & 1 & 2 & 0.1 \\
\hline & Долина р. Еруслан & 3 & 4 & 47 & 2.9 \\
\hline & Долина р. Терешка & 1 & 1 & 4 & 0.3 \\
\hline & Долина р Малый Узень & 2 & 2 & 4 & 0.3 \\
\hline & Долина р. Большой Узень & 2 & 2 & 6 & 0.4 \\
\hline & Долина р. Алтата & 1 & 1 & 44 & 2.8 \\
\hline & Всего & 5 & 6 & 1606 & 100.0 \\
\hline
\end{tabular}

Примечание. Нумерация физико-географических районов дана в соответствии с «Учебно-краеведческим атласом Саратовской области» (2013).

Note. Numbering of the physical and geographical areas is given in accordance with the "Educational and Local Historical atlas of the Saratov Region" (2013).

Несмотря на тот факт, что формирование коллекционных фондов Зоологического музея СГУ началось более века назад, современная коллекция амфибий складывается из сборов, осуществленных в основном в последние несколько десятилетий. Отмечаемая утрата более ранних сборов земноводных преимущественно связана с плохой сохранностью материала из-за низкого качества фиксирующих жидкостей, а также с отсутствием специальных работ, направленных на сохранение влажных препаратов Зоологического музея СГУ в надлежащем виде в период до 1980-х гг.
В настоящее время приоритетным направлением дальнейшей работы по формированию научной батрахологической коллекции Зоологического музея СГУ являются: исследование районов Саратовской области, сборы, с территории которых недостаточны или совсем отсутствуют, формирование мониторинговых коллекций всех видов земноводных региональной фауны, активизация работы по расширению географии и видового разнообразия сборов за счет обмена фондами с другими Зоологическими музеями России и зарубежья. 


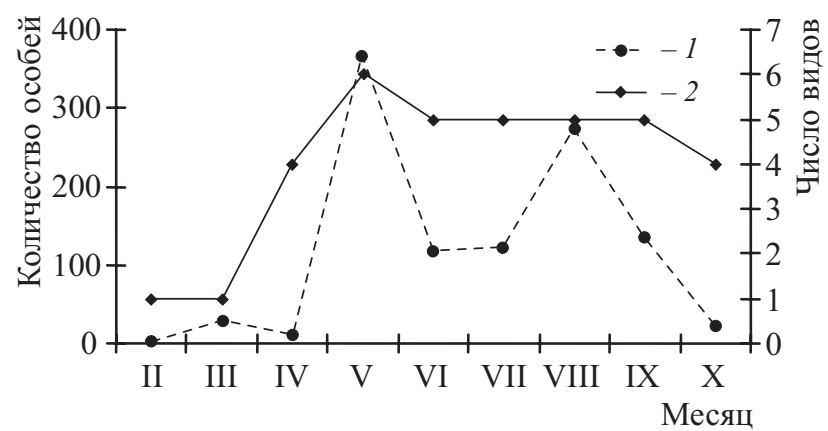

Рис. 7. Временная динамика интенсивности батрахологических сборов, осуществленных на территории Саратовской области: 1 - количество особей, 2 - число видов Fig. 7. Temporal dynamics of the intensity of bathrachological collections carried out in the Saratov region: 1 - the number of individuals, 2 - the number of species

\section{СПИСОК ВИДОВ АМФИБИЙ БАТРАХОЛОГИЧЕСКОЙ КОЛЛЕКЦИИ ЗООЛОГИЧЕСКОГО МУЗЕЯ ПО ЛАНДШАФТНО-ГЕОГРАФИЧЕСКИМ РАЙОНАМ САРАТОВСКОЙ ОБЛАСТИ}

2. Карай-Хоперский

Bombinatoridae: Bombina bombina; Pelobatidae: Pelobates fuscu.

3. Изнаир-Аркадакский

Pelobatidae: Pelobates fuscus; Ranidae: Rana arvalis, Pelophylax ridibundus.

\section{5. Елано-Альшанский}

Bombinatoridae: Bombina bombina; Pelobatidae: Pelobates fuscus.

6. Уза-Алайский

Bufonidae: Bufo viridis; Ranidae: Rana arvalis.

8. Волго-Терешкинский

Salamandridae: Lissotriton vulgaris; Bombinatoridae: Bombina bombina; Pelobatidae: Pelobates fuscus; Bufonidae: Bufo viridis; Ranidae: Rana arvalis, Pelophylax ridibundus.

\section{9. Хоперско-Терсинский}

Bombinatoridae: Bombina bombina; Pelobatidae: Pelobates fuscus; Bufonidae: Bufo viridis; Ranidae: Rana arvalis, Pelophylax ridibundus.

\section{2. Идолго-Медведицкий}

Salamandridae: Lissotriton vulgaris; Bombinatoridae: Bombina bombina; Bufonidae: Bufo viridis; Pelobatidae: Pelobates fuscus; Ranidae: Pelophylax ridibundus.
14. Средне-Терешкинский

Bufonidae: Bufo viridis; Pelobatidae: Pelobates fuscus; Ranidae: Rana arvalis, Pelophylax ridibundus.

15. Нижне-Терешкинский

Bufonidae: Bufo viridis; Ranidae: Rana arvalis, Pelophylax ridibundus.

16. Чардымо-Курдюмский

Bufonidae: Bufo viridis; Ranidae: Pelophylax ridibundus.

18. Волго-Карамышский

Bombinatoridae: Bombina bombina; Bufonidae: Bufo viridis; Pelobatidae: Pelobates fuscus; Ranidae: Pelophylax ridibundus.

21. Сестра-Камеликский

Bufonidae: Bufo viridis; Ranidae: Rana arvalis.

22. Волжский террасовый центральный

Bombinatoridae: Bombina bombina; Pelobatidae: Pelobates fuscus; Bufonidae: Bufo viridis; Ranidae: Pelophylax ridibundus.

23. Караманский

Bufonidae: Bufo viridis; Ranidae: Rana arvalis, Pelophylax ridibundus.

24. Верхне-Узенский

Pelobatidae: Pelobates fuscus; Bufonidae: Bufo viridis; Ranidae: Rana arvalis, Pelophylax ridibundus.

\section{7. Еруслано-Бизюкский}

Bombinatoridae: Bombina bombina; Bufonidae: Bufo viridis; Pelobatidae: Pelobates fuscus; Ranidae: Rana arvalis, Pelophylax ridibundus.

29. Больше-Узенский

Ranidae: Rana arvalis, Pelophylax ridibundus.

32. Приузенский

Pelobatidae: Pelobates fuscus; Ranidae: Pelophylax ridibundus.

33. Интразанальные ландшафты долин малых рек:

Острова р. Волги

Ranidae: Rana arvalis, Pelophylax ridibundus.

Долина р. Нахой

Ranidae: Rana arvalis. 
Э. И. Кайбелева, М. В. Ермохин, Е. Н. Кондратьев и др.

Долина р. Хопер

Pelobatidae: Pelobates fuscus.

Долина р. Медведица

Salamandridae: Lissotriton vulgaris; Bombinatoridae: Bombina bombina; Pelobatidae: Pelobates fuscus; Bufonidae: Bufo viridis; Ranidae: Rana arvalis, Pelophylax ridibundus.

\section{Долина р. Большой Иргиз}

Bombinatoridae: Bombina bombina; Pelobatidae: Pelobates fuscus; Bufonidae: Bufo viridis; Ranidae: Rana arvalis, Pelophylax ridibundus.

Долина p. Терса

Ranidae: Pelophylax ridibundus.

Долина р. Еруслан

Bombinatoridae: Bombina bombina; Bufonidae: Bufo viridis; Ranidae: Rana arvalis, Pelophylax ridibundus.

Долина p. Терешка

Ranidae: Pelophylax ridibundus.

Долина р. Малый Узень

Pelobatidae: Pelobates fuscus; Bufonidae: Bufo viridis.

Долина р. Большой Узень

Pelobatidae: Pelobates fuscus; Bufonidae: Bufo viridis.

Долина р. Алтата

Ranidae: Pelophylax ridibundus.

\section{СПИСОК ЛИТЕРАТУРЫ}

Бажанов В. С. 1930. Список гадов Бузулукского и Пугачевского уезда б. Самарской губ., собранных в 1928 году // Средне-Волжская краевая станция защиты растений. Бюл. за 1926 - 1928 гг. Самара. С. 69.

Белянин А. Н., Шляхтин Г. В., Сонин К. А. 1989. Изменение фауны позвоночных животных как показатель состояния экосистем Волги // Экологические проблемы Волги : тез. докл. регион. конф. Саратов : Изд-во Сарат. ун-та. Ч. 2. С. 152.

Бенинг А. Л. 1913. Материалы по гидрофауне придаточных систем реки Волги. І. Материалы по гидрофауне р. Б. Иргиз // Работы Волжской биологической станции. T. IV, № 5. С. 1 - 50.

Бенинг А. Л. 1921. Материалы по гидрофауне придаточных систем реки Волги. III. Материалы по гидрофауне р. Еруслан // Работы Волжской биологической станции. Т. V, № 4 - 5. С. $307-308$.
Богданов М. Н. 1871. Птицы и звери черноземной полосы Поволжья и долины Средней и Нижней Волги (био-географические материалы) // Тр. о-ва естествоиспытателей при Императорском Казан. ун-те. T. 1, № 1. C. $4-158$.

Гаранин В. И. 1981. О некоторых аспектах роли амфибий и рептилий в антропогенном ландшафте // Вопросы герпетологии : автореф. докл. V Всесоюз. герпетол. конф. Л. : Наука. Ленингр. отд-ние. С. 35 - 36.

Гаранин В. И. 1983. Земноводные и пресмыкающиеся Волжско-Камского края. М. : Наука. 176 с.

Дгебуадзе Ю. Ю. 2014. Чужеродные виды в Голарктике : некоторые результаты и перспективы исследований // Рос. журн. биологических инвазий. T. 7, № 1. C. $2-8$.

Доценко И. Б. 2003. Каталог коллекций Зоологического музея ННПМ НАН Украины. Змеи / Зоол. музей ННПМ НАН Украины. Киев. 86 с.

Житков Б. М. 1900. Очерки природы Среднего Поволжья // Естествознание и география. № 7. С. $1-21$.

Завьялов Е. В., Аникин В. В., Шляхтин Г. В., Туровцев В. Д., Баракин А. А., Нецветаев А. Г. 1994. Исследование клинических эффектов иприта и люизита на развитие амфибий // Вестн. Удмурт. гос. унта. Спец. вып. С. 185 - 193.

Завьялов Е. В., Шляхтин Г. В., Табачишин В. Г., Сторожилова Д. А. 1996. Использование популяций земноводных и пресмыкающихся в индикации сероводородного загрязнения // Проблемы экологической безопасности Н. Поволжья в связи с разработкой и эксплуатацией нефтегазовых месторождений с высоким содержанием сероводорода. Саратов : Изд-во Сарат. ун-та. С. $118-119$.

Завьялов Е. В., Табачишин В. Г. 1998 а. Современное состояние популяций амфибий и рептилий на территории Астраханского газоконденсатного месторождения // Проблемы экологической безопасности Н. Поволжья в связи с разработкой и эксплуатацией нефтегазовых месторождений с высоким содержанием сероводорода. Саратов : Изд-во Сарат. ун-та. C. $142-148$.

Завьялов Е. В., Табачишии В. Г. 1998 б. Амфибии и рептилии охраняемых природных территорий Саратовской области // Роль охоронюваних природних територій у збереженні біорізноманіття : матеріали конф. Канів : Фітосоціоцентр. С. $183-184$.

Кайбелева Э. И., Завьялов Е. В., Табачишин В. Г. 2004. Эколого-кариологические особенности озерных лягушек севера Нижнего Поволжья // Поволж. экол. журн. № 3. С. $318-319$.

Кайбелева Э. И., Завьялов Е. В., Табачишин В. Г. 2005. Особенности кариотипа озерных лягушек на севере Саратовского Правобережья // Актуальные проблемы экологической физиологии, биохимии и генетики животных : материалы междунар. науч. конф. Саранск : Изд-во Морд. ун-та. С. 91 - 93.

Кайбелева Э. И., Красникова Ю. А., Табачишина И. Е. 2006. Описание кариотипа зеленой жабы 
Научная коллекция амфибий Зоологического музея Саратовского университета

(Bufo viridis) из Саратовского Заволжья // Современная герпетология. Т. 5/6. С. $104-106$.

Кайбелева Э. И., Завьялов Е. В., Табачишин В. Г. 2010. Особенности межпопуляционной изменчивости кариотипа озерной лягушки Rana (Pelophylax) ridibunda на севере Нижнего Поволжья // Современная герпетология. Т. 10, вып. 1/2. С. $57-60$.

Кубанцев Б. С. 1999. Батрахо- и герпетологические исследования в Нижнем Поволжье // Актуальные проблемы герпетологии и токсикологии. Вып. 2. C. $9-19$.

Кулагин Н. М. 1888. Списки и описание предметов, находящихся в Зоологическом музее Императорского Московского университета. Отдел 2 : Списки и описание коллекции земноводных и пресмыкающихся музея // Изв. Императ. о-ва любителей естествознания, антропологии и этнографии. T. LVI, вып. 2.39 с.

Никольский А. М. 1918. Фауна Россіи и сопредельныхъ странъ. Земноводныя (Amphibia). Пг. : Типография Императ. Академіи наук. 322 с.

Носова О. Н. 1984. Пищевая специализация в разных экологических группах бесхвостых амфибий // Вопросы биологии растений и животных Поволжья. Саратов : Изд-во Сарат. ун-та. С. $34-44$.

Носова О. Н., Шляхтин Г. В., Павловцева Т. В. 1987. Питание экологически близких видов амфибий - Pelobates fuscus (Laur. 1768) и Bufo viridis (Laur. 1768) // Вопросы экологии и охраны природы в Нижнем Поволжье. Структура и организация популяции. Саратов : Изд-во Сарат. ун-та. С. 86 - 92.

Ососковъ П. А., Коростелевъ Н. А., Гавриловъ Н. Г., Сырневъ И. Н. 1901. Среднее и Нижнее Поволжье и Заволжье // Россія : Полное географическое описаніе нашего Отечества. Настольная и дорожная книга для русскихъ людей. СПб. : Издание А. Ф. Девріена. Т. 6. С. 88 - 95.

[Паллас П.С.] 1773. П. С. Палласа доктора медицины, профессора Натуральной исторіи и члена Россійской Императорской академіи наукЂ, и Санктпетербурскаго Вольного экономическаго общества, также Римской Императорской академіи изпытателей естетства и Королевскаго Аглинскаго ученаго собранія, Путешествіе по разнымЂ провинціямЂ Россійской Имперіи. СПб. : Императ. Акад. наукЂ. Ч. 1. 658 + 117 с.

[Паллас П.С.] 1788. Палласа доктора медицины, профессора Натуральной исторіи и члена Россійской Императорской академіи наукЂ, и Санктпетербурскаго Вольного экономическаго общества, также Римской Императорской академіи изпытателей естетства и Королевскаго Аглинскаго ученаго собранія, Путешествіе по разнымЂ провинціямЂ Россійской Имперіи. СПб. : Императ. Акад. наукЂ. Ч. 3. 480 с.

Писанеи Е. М. 2003. Каталог коллекций Зоологического музея ННПМ НАН Украины. Хвостатые земноводные (Amphibia: Caudata) / Зоол. музей ННПМ НАН Украины. Киев. 148 с.

Полуконова А. В., Демин А. Г., Ермохин М. В., Табачишин В. Г. 2013 а. Новые гаплотипы чесночни- цы обыкновенной Pelobates fuscus (Laurenti, 1768) из популяций в долине реки Медведица (Саратовская область) // Биология внутренних вод : материалы XV шк.-конф. молодых ученых / Ин-т биологии внутренних вод РАН. Борок. С. $304-308$.

Полуконова А. В., Демин А. Г., Полуконова Н. В., Ермохин М. В., Табачишин В. Г. 2013 б. Молекулярно-генетическое исследование локальных популяций чесночницы обыкновенной Pelobates fuscus (Laurenti, 1768 ) долины р. Медведица (Саратовская область) по участку гена мтДНК - Cуt $B$ // Современная герпетология. Т. 13 , вып. 3/4. С. $117-121$.

Попов В. П. 1901. Справочная книга Пензенской губерніи на 1901 годъ. Пенза : Изд. Пензенскаго Губернскаго статистическаго комитета. Т. 2.57 с.

Россолимо О. Л., Павлинов И. Я. 1981. Каталог териологических коллекций зоологического музея МГУ. М. : Изд-во МГУ. 68 с.

[Рычков П. И.] 1762. Топография Оренбургская, то есть : обстоятельное описание Оренбургской губернии, сочиненное коллежским советником и императорской Академии наук корреспондентом Петром Рычковым. СПб. : Императ. Академия наук. Ч. 1. 331 c. ; Ч. 2.263 c.

[Рычков П. И.] 1887. Топография Оренбургской губернии. Сочинение П. И. Рычкова. Оренбург : Тип. Б. Бреслина. 406 с.

Силантьев А. А. 1894. Фауна Падов, имения В. Л. Нарышкина Балашовского уезда Саратовской губернии // Естественно-исторический очерк имения Пады. СПб. : Типо-литограф. Е. Евдокимова. С. 225 - 437.

Сторожилова Д. А. 2002. Эколого-морфологический анализ популяционной структуры и изменчивости бесхвостых амфибий (Amphibia, Anura) ceверной части Нижнего Поволжья : автореф. дис. ... канд. биол. наук. Самара, 2002. 19 с.

Сторожилова Д. А., Шляхтин Г. В. 2000. Изменчивость зеленой жабы Нижнего Поволжья // Coвременная герпетология. Т. 1. С. $52-55$.

Сторожилова Д. А., Шляхтин Г. В., Табачииин В. Г., Завьялов Е. В. 1998. Эколого-морфологические особенности краснобрюхой жерлянки (Bombina bombina L., Discoglossidae) северной части Нижнего Поволжья // Вопросы биоценологии. Саратов : Изд-во Сарат. ун-та. С. 104 - 109.

Табачишин В. Г., Завьялов Е. В., Сторожилова Д. А. 1997. Таксономический статус краснобрюхой жерлянки (Bombina bombina) Саратовской области и сопредельных территорий // Проблемы экологии, биоразнообразия и охраны прибрежноводных экосистем : тез. докл. Х Всерос. конф. молодых ученых / Ин-т биологии внутренних вод им. И. Д. Папанина РАН. Борок. С. 53 - 54.

Табачишин В. Г., Сторожсилова Д. А., Завьялов Е. В. 1999. Распространение и морфологическая характеристика популяций краснобрюхой жерлянки (Bombina bombina) в Нижнем Поволжье // Вторая конференция герпетологов Поволжья : тез. докл. / Ин-т экологии Волжского бассейна РАН. Тольятти, 1999. С. 49 - 50. 
Табачишин В. Г., Сторожилова Д. А., Завьялов E. В. 2000. Земноводные охраняемых территорий Саратовской области // Проблемы природопользования и сохранения биоразнообразия в условиях опустынивания : тез. докл. межрегион. науч.-практ. конф. Волгоград: Всерос. НИИ агролесомелиорации. C. $120-121$.

Терентьев П. В., Чернов С. А. 1949. Определитель пресмыкающихся и земноводных. М. ; Л. : Сов. наука. 340 c.

Учебно-краеведческий атлас Саратовской области / отв. ред. В. З. Макаров. Саратов : Изд-во Сарат. ун-та, 2013. $143 \mathrm{c}$.

Чернов С. А. 1937. Пресмыкающиеся (Reptilia) и земноводные (Amphibia) // Животный мир CCCP. М. ; Л. : Изд-во АН СССР. Т. 1. С. $326-345$.

Чернов С. А. 1945. Пресмыкающиеся и земноводные // Успехи биологических наук в СССР за двадцать лет. М. ; Л. : Изд-во АН СССР. С. 115 - 118.

Шляхтин Г. В. 1980. О некоторых сезонных изменениях в нервной ткани пищеварительного тракта пойкилотермных животных // Физиологическая и популяционная экология животных. Саратов : Изд-во Сарат. ун-та. Вып. 6. С. 126 - 131.

Шляхтин Г. В. 1985 а. Трофические ниши совместно обитающих видов бесхвостых амфибий // Экология. № 6. С. $24-32$.

Шляхтин Г.В. 1985 б. Фенетический анализ окраски спины озерной лягушки // Фенетика популяций : материалы III Всесоюз. совещ. М. : Ин-т биологии развития им. Н. К. Кольцова. С. $173-174$.

Шляхтин Г. В. 1987. Экология питания и адаптивные особенности пищеварительного тракта зимоспящих позвоночных : автореф. дис. ... д-ра биол. наук. Саратов. 24 с.

Шляхтин Г. В., Голикова В. Л. 1986. Методика полевых исследований экологии амфибий и рептилий. Саратов : Изд-во Сарат. ун-та. 78 с.

Шляхтин Г. В., Завьялов Е. В. 1997. Динамика пищевого спектра озерной лягушки Rana ridibunda на примере различных вариантов экотонных систем «вода-суша» // Проблемы изучения краевых структур биоценозов : тез. докл. Всерос. семинара. Саратов : Изд-во Сарат. ун-та. С. 27.

Шляхтин Г. В., Беляченко А. В., Каширская Е. В., Завьялов Е. В. 1994. Генезис и пространственно-временная структура экотонов верхней зоны Волгоградского водохранилища // Биология, экология, биотехнология и почвоведение. М. : Изд-во МГУ. С. 76 - 91.

Шляхтин Г. В., Завьялов Е. В., Аникин В. В., Малинина Ю. А. 1996. Икра и личинки амфибий в биоиндикации токсических веществ // Тез. VII съезда гидробиол. о-ва РАН. Казань : Полиграф Казань, 1996. Т. 3. С. $100-102$.

Шляхтин Г. В., Завьялов Е. В., Якушев Н. Н., Табачишин В. Г., Сторожилова Д. А., Банадык О. В. $2001 a$. Сезонная динамика питания краснобрюхой жерлянки Bombina bombina (Discoglossidae, Anura,
Amphibia) в условиях Саратовской области // Вопросы биологии, экологии, химии и методики обучения. Саратов : Сигма-плюс. Вып. 4. С. 48 - 50.

Шляхтин Г. В., Завьялов Е. В., Шляхтина Ю. В., Табачишин В. Г. 2001 б. Функциональное значение озерной лягушки в экосистемах Волгоградского водохранилища // Фундаментальные и прикладные аспекты функционирования водных экосистем : проблемы и перспектывы гидробиологии и ихтиологии в XXI веке : материалы Всерос. науч. конф. Саратов : Изд-во Сарат. ун-та. С. $199-202$.

Шляхтин Г. В., Беляченко А. В., Мосолова Е. Ю., Табачииин В. Г. 2014. Биологическая структура и динамика водно-наземных экотонов верхней зоны Волгоградского водохранилища // Поволж. экол. журн. № 1. С. $74-81$.

Щербак Н. Н., Токарь А. А., Кириленко И. В. 1997. Каталог коллекций Зоологического музея ННПМ НАН Украины. Гекконовые ящерицы (Reptilia : Sauria, Geckonidae) / Зоол. музей ННПМ НАН Украины. Киев. 46 с.

Boettger O. 1898. Katalog der Reptilien-Sammlung im Museum der Senckenbergisch en Naturforschenden Gesellschaft im Frankfurt am Main. Frankfurt am Main. Bd. 2, teil 2. $160 \mathrm{~S}$.

Boulenger G. A. 1893. Catalogue of snakes in the British Museum (Natural History). Vol. I. Containing the families Typhlopidae, Glauconiidae, Boidae, Ilysiidae, Uropeltidae, Xenopeltidae, and Colubridae Aglyphae. London : Trustees of the British Museum. $448 \mathrm{p}$.

Boulenger G. A. 1894. Catalogue of snakes in the British Museum (Natural History). London. Vol. 2. 382 p.

Boulenger G. A. 1896. Catalogue of snakes in the British Museum (Natural History). Vol. 3. Containing the Colubridae (Opisthoglyphae and Proteroglyphe), Amblycephalidae and Viperidae. London : Trustees of the British Museum. 727 p.

Cope E. D. 1860. Catalogue of the Colubridae in the Museum of the Academy of Natural Sciences of Philadelphia, with notes and description of new species. Part 2 // Proc. Acad. Nat. Sci. Philadelphia. № 12. P. $241-266$.

Fischer G. 1822. Museum Historiae Naturalis Universitatis Caesareae Mosquensis. I : Animalia. Mosquae : Typis Universitatis Caesareae. $76 \mathrm{p}$.

Gunther A. C. 1858. Catalogue of the colubrinae snakes in the collection of the British Museum. London : British Museum (Natural History). 282 p.

Muller F. 1878. Katalog der im Museum und Universitatskabinet zu Basel aufge stellten Amphibien und Reptilien nebst Anmerkungen. Basel. Vol. 6. P. $551-709$.

[Pallas P. S.] 1771. P. S. Pallas D. A. D. Professors der Natur-Geschichte und ordentlichen Mitgliedes der Russisch-Kayserlichen Academie d. W. der freyen oeconomischen Gesellschaft in St. Petersburg, wie auch der Römisch-Kayserlichen Academie der Naturforscher und Königl. Engl. Societät; Reise durch verschiedene Provinzen des Russischen Reichs. Erster Teil. SPb. : Kayserliche Academie der Wissenschaften. 504 S. 
Научная коллекция амфибий Зоологического музея Саратовского университета

[Pallas P. S.] 1776. P. S. Pallas D. A. D. Professors der Natur-Geschichte und ordentlichen Mitgliedes der Russisch-Kayserlichen Academie d. W. der freyen oeconomischen Gesellschaft in St. Petersburg, wie auch der Römisch-Kayserlichen Academie der Naturforscher und Königl. Engl. Societät; Reise durch verschiedene Provinzen des Russischen Reichs. Dritter Teil. SPb. : Kayserliche Academie der Wissenschaften. 760 S.
Pallas P. S. 1814. Zoographia Rosso-Asiatica, sistens omniun animalium in extenso Imperio Rossico et adjacentibus maribus observatorum recensionem, domicilia, mores et descriptions, anatomen atque icones plurimorum; auctore Petro Pallas, eq. Aur. Academico Petropoliano. Tomus III. Animalia monocardia seu frigidi sanguinis Imperii Rosso-Asiatici. Petropoli : ex officina Caes. Academiae Scientarum. 428 p.

\section{Образец для цитирования:}

Кайбелева Э. И., Ермохин М. В., Кондратьев Е. Н., Мосолова Е. Ю., Табачишин В. Г., Шляхтин Г. В. 2019. Научная коллекция амфибий Зоологического музея Саратовского университета как основа регионального кадастpa // Современная герпетология. Т. 19, вып. 3/4. C. 95 - 124. DOI: https://doi.org/10.18500/1814-6090-2019-19-3-495-124 
Э. И. Кайбелева, М. В. Ермохин, Е. Н. Кондратьев и др.

\title{
Amphibian Scientific Collection of the Zoological Museum of Saratov State University as the Basis for the Regional Cadastre
}

\author{
EImira I. Kaybeleva ${ }^{1}$, kaibeleva.elmira@yandex.ru \\ Mikhail V. Yermokhin 1, https://orcid.org/0000-0001-6377-6816; ecoton@rambler.ru \\ Evgeny N. Kondratiev ${ }^{1}$, sumeru28896@gmail.com \\ Ekaterina Yu. Mosolova ${ }^{1}$, ekmosolova@mail.ru \\ Vasily G. Tabachishin ${ }^{2}$, https://orcid.org/0000-0002-9001-1488; tabachishinvg@sevin.ru \\ Gennady V. Shlyakhtin ${ }^{1}$, https://orcid.org/0000-0002-6005-5340; genvic41@mail.ru \\ ${ }^{1}$ Saratov State University \\ 83 Astrakhanskaya St., Saratov 410012, Russia \\ ${ }^{2}$ Saratov Branch of A. N. Severtsov Institute of Ecology and Evolution, Russian Academy of Sciences \\ 24 Rabochaya St., Saratov 410028, Russia
}

Received 24 December 2018, revised 17 May 2019, accepted 29 May 2019

\begin{abstract}
The characteristic is given and the taxonomic structure of the modern bathrachological collection of the Zoological Museum of the Saratov National Research State University named after N. G. Chernyshevsky is analyzed. Currently, it has 1903 specimens of amphibians belonging to 46 species of 13 families. The Ranidae family is the most fully presented one $(43.3 \%$ of the total number of storage units). In total, the Ranidae collection contains 711 specimens of 10 frog species, of which 2 species (569 specimens) account for Saratov regional collections. In addition, the collections of Bombinatoridae and toads are relatively vast, making up 18.2 and $17.9 \%$ of the total collection by volume, respectively.
\end{abstract}

Keywords: amphibians, collection, zoological museum.

DOI: https://doi.org/10.18500/1814-6090-2019-19-3-4-95-124

This article is an open access article distributed under the terms and conditions of the Creative Commons Attribution 4.0 License

\section{REFERENCES}

Bazhanov V. S. List of reptiles of the Buzuluksky and Pugachevsky districts of the former Samarskaya province, collected in 1928. Sredne-Volzhskaia kraevaia stantsiia zashchity rastenii. Biull. za 1926 - 1928 gg. [Middle-Volga Regional Plant Protection Station. Bulletin for 1926-1928]. Samara, 1930, pp. 69 (in Russian).

Belyanin A. N., Shlyakhtin G. V., Sonin K. A. Changes in the fauna of vertebrate animals as an indicator of the condition of the Volga ecosystems. In: Ekologicheskie problemy Volgi: tezisy dokladov regional'noi konferentsii [Ecological Problems of the Volga: Abstracts of the Reports of the Regional Conference]. Saratov, Izdatel'stvo Saratovskogo universiteta, 1989, part 2, pp. 152 (in Russian).

Behning A. Materialien zur Hydrofauna der Nebengewasser der Wolga. I. Materialien zur Hydrofauna des Flusses Irgis. Arbeiten der Biologischen WolgaStation, 1913, Bd. IV, no. 5, S. 1-50 (in Russian).

Behning A. Materialien zur Hydrofauna der Nebengewasser der Wolga. III. Materialien zur Hydrofauna des Flusses Yeruslana. Arbeiten der Biologischen WolgaStation, 1921, Bd. V, no. 4-5, S. 307-308 (in Russian).

Bogdanov M. N. Birds and mammals of the chernozem zone in the Volga region and and valleys of both Middle Volga and Lower Volga (biogeographic materi- als). Proceedings of the Society of Naturalists in the Imperial Kazan University, 1871, vol. 1, no. 1, pp. 4-158 (in Russian).

Garanin V. I. On some aspects of the role of amphibians and reptiles in the anthropogenic landscape. The Problems of Herpetology: Abstracts of Fifth Herpetological Conference. Leningrad, Nauka Publ., 1981, pp. 35-36 (in Russian).

Garanin V. I. Zemnovodnye i presmykaiushchiesia Volzhsko-Kamskogo kraia [Amphibians and Reptiles of Volga-Kama Region]. Moscow, Nauka Publ., 1983. 175 p. (in Russian).

Dgebuadze Yu. Yu. Invasions of Alien Species in Holarctic: Some Results and Perspective of Investigations. Russian J. of Biological Invasions, 2014, vol. 5, no. 2 , pp. $61-64$.

Dotsenko I. B. Catalogue of Collections of the Zoological Museum NMNH, NAS of Ukraine. The Snakes. Kiev, Zoomuseum NMNH NAS of Ukraine Publ., 2003. 86 p. (in Russian).

Zhitkov B. M. Essays on the nature of the Middle Volga. Estestvoznanie i geografiia, 1900, no. 7, pp. 1-21 (in Russian)

Zavialov E. V., Anikin V. V., Shlyakhtin G. V., Turovtsev V. D., Barakin A. A., Netsvetaev A. G. Study of the clinical effects of mustard gas and lewisite on the 
development of amphibians. Bulletin of Udmurt University, 1994, special iss., 185-193 (in Russian).

Zavialov E. V., Shlyakhtin G. V., Tabachishin V. G., Storozhilova D. A. The use of amphibian and reptile populations in the indication of hydrogen sulfide pollution. In: Problemy ekologicheskoi bezopasnosti N. Povolzh'ia v sviazi s razrabotkoi $i$ ekspluatatsiei neftegazovykh mestorozhdenii s vysokim soderzhaniem serovodoroda [Problems of environmental safety of the Lower Volga region in connection with the development and operation of oil and gas fields with a high content of hydrogen sulfide]. Saratov, Izdatel'stvo Saratovskogo universiteta, 1996, pp. 118-119 (in Russian).

Zavialov E. V., Tabachishin V. G. Current status of populations of amphibians and reptiles in the territory of the Astrakhan gas condensate field. In: Problemy ekologicheskoi bezopasnosti N. Povolzh'ia v sviazi s razrabotkoi $i$ ekspluatatsiei neftegazovykh mestorozhdenii s vysokim soderzhaniem serovodoroda [Problems of environmental safety of the Lower Volga region in connection with the development and operation of oil and gas fields with a high content of hydrogen sulfide]. Saratov, Izdatel'stvo Saratovskogo universiteta, 1998 a, pp. 142-148 (in Russian).

Zavialov E. V., Tabachishin V. G. Amphibians and Reptiles of Protected Natural Areas of the Saratov region. In: Rol' ohoronjuvanyh pryrodnyh terytorij u zberezhenni bioriznomanittja: materialy konferencii [The Role of Protected Areas in Biodiversity Conservation: Materials Conf.]. Kaniv, Fitosotsiotsentr Publ., 1998 b, pp. 183184 (in Russian).

Kaybeleva E. I., Zavialov E. V., Tabachishin V. G. Ecologo-caryological peculiarities of the marsh frogs on the north of the Lower Volga region. Povolzhskiy J. of Ecology, 2004, no. 3, pp. 318-319 (in Russian).

Kaybeleva E. I., Zavialov E. V., Tabachishin V. G. Features of the karyotype of marsh frogs in the north of the Saratov Right Bank Region. In: Aktual'nye problemy ekologicheskoi fiziologii, biokhimii i genetiki zhivotnykh : materialy mezhdunar. nauch. konf. [Actual Problems of Ecological Physiology, Biochemistry and Animal Genetics: Proc. International Scientific Conf.]. Saransk, Izdatel'stvo Mordovskogo universiteta, 2005, pp. 91-93 (in Russian).

Kaybeleva E. I., Krasnikova Yu. A., Tabachishina I. E. Karyotype of Bufo viridis from the Saratov TransVolga Region. Current Studies in Herpetology, 2006, vol. 5-6, pp. 104-106 (in Russian).

Kaybeleva E. I., Zavialov E. V., Tabachishin V. G. Features of the interpopulational karyotype variability of Rana (Pelophylax) ridibunda in the northern LowerVolga region. Current Studies in Herpetology, 2010, vol. 10, iss. 1-2, pp. 57-60 (in Russian).

Kubantsev B. S. Batracho- and herpetological studies in the Lower Volga Region. Actual Problems of Herpetology and Toxicology, 1999, iss. 2, pp. 9-19 (in Russian).

Kulagin N. M. Lists and descriptions of objects in the Zoological Museum of the Imperial Moscow University. Division 2: Lists and description of the collection of amphibians and reptiles of the museum. News of the Imperial Society of Lovers of Natural Science, Anthropology and Ethnography, 1888, vol. LVI, iss. 2. 39 p. (in Russian).

Nikolsky A. M. Fauna of Russia and Adjacent countries. Amphibia. Petrograd, Tipografiia Imperatorskoi Akademii Nauk, 1918. 322 p. (in Russian).

Nosova O. N. Trophic specialization in different ecological groups of anuran amphibians. In: Voprosy biologii rastenii $i$ zhivotnykh Povolzh'ia [Issues of Plant and Animal Biology of the Volga Region]. Saratov, Izdatel'stvo Saratovskogo universiteta, 1984, pp. 34-44

Nosova O. N., Shlyakhtin G. V., Pavlovtseva T. V. Feeding of ecologically close species of amphibians Pelobates fuscus (Laur. 1768) and Bufo viridis (Laur. 1768). In: Voprosy ekologii i okhrany prirody v Nizhnem Povolzh'e. Struktura i organizatsiia populiatsii [Ecology and Nature Conservation Issues in the Lower Volga Region. The structure and organization of the population]. Saratov, Izdatel'stvo Saratovskogo universiteta, 1987, pp. 86-92 (in Russian).

Ososkov P. A., Korostelev N. A., Gavrilov N. G., Syrnev I. N. Middle and Lower Volga and Trans-Volga regions. In: Rossiia: Polnoe geograficheskoe opisanie nashego otechestva. Nastol'naia i dorozhnaia kniga dlia russkikh liudei [Russia: Full geographical description of our country. Handbook and travel book for Russian people]. SPb., Izdanie A. F. Devriena, 1901, vol. 6, pp. 88-95 (in Russian).

[Pallas P. S.] P. S. Pallasa doktora meditsiny, professora Natural'noi istorii i chlena Rossiiskoi Imperatorskoi akademii nauk, i Sankt-peterburskago Vol'nogo ekonomicheskago obshchestva, takzhe Rimskoi Imperatorskoi akademii izpytatelei estetstva i Korolevskago Aglinskago uchenago sobraniia, Puteshestvie po raznym provintsiiam Rossiiskoi Imperii [P. S. Pallas, Doctor of Medicine, Professor of Natural History and a member of the Russian Imperial Academy of Sciences, and the St. Petersburg Free Economic Society, also Roman of the Imperial Academy of Natural History and the Royal English scientific collection, Traveling to different provinces of the Russian Impire]. SPb., Imperatorskaia Akademiia nauk Publ., 1773, part $1.658+117$ p. (in Russian).

[Pallas P. S.] . Pallasa doktora meditsiny, professora Natural'noi istorii i chlena Rossiiskoi Imperatorskoi akademii nauk, i Sankt-peterburskago Vol'nogo ekonomicheskago obshchestva, takzhe Rimskoi Imperatorskoi akademii izpytatelei estetstva i Korolevskago Aglinskago uchenago sobraniia, Puteshestvie po raznym provintsiiam Rossiiskoi Imperii [Pallas, Doctor of Medicine, Professor of Natural History and a member of the Russian Imperial Academy of Sciences, and the St. Petersburg Free Economic Society, also Roman of the Imperial Academy of Natural History and the Royal English scientific collection, Traveling to different provinces of the Russian Impire]. SPb., Imperatorskaia Akademiia nauk Publ., 1788, part 3. 480 p. (in Russian).

Pisanets E. M. Catalogue of Collections of the Zoological Museum NMNH, NAS of Ukraine. The Tailed Amphibians (Amphibia: Caudata). Kyiv, Zoomuseum NMNH NAS of Ukraine Publ., 2003. 148 p. (in Russian). 
Polukonova A. V., Djomin A. G., Yermokhin M. V., Tabachishin V. G New haplotypes of common spadefoot toad Pelobates fuscus (Laurenti, 1768) from populations in the Medveditsa river valley (Saratov region). Biologiia vnutrennikh vod: materialy XV shkoly-konferentsii molodykh uchenykh [Biology of Inland Waters: Proceedings of the XV School-Conference of Young Scientists]. Borok, Institut biologii vnutrennikh vod RAN Publ., 2013 a, pp. 304-308 (in Russian).

Polukonova A. V., Djomin A. G., Polukonova N. V., Yermokhin M. V., Tabachishin V. G. A moleculargenetic study of Spadefoot toad Pelobates fuscus (Laurenti, 1768) local populations from the Medveditsa river valley (Saratov region) by mtDNA - CytB gene. Current Studies in Herpetology, 2013 b, vol. 13, iss. 3-4, pp. 117-121 (in Russian).

Popov V. P. Spravochnaia kniga Penzenskoi gubernii na 1901 god [A reference book of the Penza province for 1901]. Penza, Izd. Penzenskago Gubernskago statisticheskago komiteta, 1901, vol. 2, 57 p. (in Russian).

Rossolimo O. L., Pavlinov I. Ya. Katalog teriologicheskikh kollektsii zoologicheskogo muzeia MGU [Catalogue of mammal collections in the Zoological Museum of MSU]. Moscow, Izdatel'stvo MGU, 1981. 68 p. (in Russian).

Rychkov P. I. Topografiia Orenburgskaia, to est': obstoiatel'noe opisanie Orenburgskoi gubernii, sochinennoe kollezhskim sovetnikom i imperatorskoi Akademii nauk korrespondentom Petrom Rychkovym [Topography Orenburg, that is: a detailed description of the Orenburg province, Corresponding author Peter Rychkov, compiled by the collegiate adviser and the Imperial Academy of Sciences]. St. Petersburg, Imperatorskaia Akademiia nauk, 1762, part 1, 331 p.; part 2, 263 p. (in Russian).

Rychkov P. I. Topografiia Orenburgskoi gubernii. Sochinenie P. I. Rychkova [Topography of the Orenburg province. Composition by P. I. Rychkov]. Orenburg, Tipografiia B. Breslina, 1887. 406 p. (in Russian).

Silantev A. A. Fauna of Pady, estate of V. L. Naryshkin, Balashov district of Saratov province. In: Estestvenno-istoricheskii ocherk imeniia Pady [Pady. Estate of V.A. Naryshkin: A Natural History Essay]. St. Petersburg, Tipo-litografiia E. Evdokimov, 1894, pp. 225-437 (in Russian).

Storozhilova D. A. 2002. Ekologo-morfologicheskii analiz populiatsionnoi struktury i izmenchivosti beskhvostykh amfibii (Amphibia, Anura) severnoi chasti Nizhnego Povolzh'ia [Ecological and morphological analysis of the population structure and variability of anuran amphibians (Amphibia, Anura) in the northern part of the Lower Volga Region]. Thesis Diss. Cand. Sci. (Biol.). Samara, 2002. 19 p. (in Russian).

Storozhilova D. A., Shlyakhtin G. V. Variability of Green Toads in the Lower Volga area. Current Studies in Herpetology, 2000, vol. 1, pp. 52-55 (in Russian).

Storozhilova D. A., Shlyakhtin G. V., Tabachishin V. G., Zavialov E. V. Ecological and morphological features of the european fire-bellied toad (Bom- bina bombina L., Discoglossidae) in the northern part of the Lower Volga. In: Voprosy biotsenologii [Biocenology Issues]. Saratov, Izdatel'stvo Saratovskogo universiteta, 1998, pp. 104-109 (in Russian).

Tabachishin V. G., Zavialov E. V., Storozhilova D. A. The taxonomic status of the European fire-bellied toad (Bombina bombina) of the Saratov region and adjacent territories. Problemy ekologii, bioraznoobraziia $i$ okhrany pribrezhnovodnykh ekosistem: tezisy dokladov X Vserossiiskoi konferentsii molodykh uchenykh [Problems of Ecology, Biodiversity and Protection of Coastal-Water Ecosystems: Abstracts X All-Russian Conference of young scientist]. Borok, Institut biologii vnutrennikh vod im. I. D. Papanina RAN Publ., 1997, pp. 53-54 (in Russian).

Tabachishin V. G., Storozhilova D. A., Zavialov E. V. Distribution and morphological characteristics of populations of european fire-bellied toad (Bombina bombina) in the Lower Volga region. In: Vtoraia konferentsiia gerpetologov Povolzh'ia: tez. dokl. [Second Conference of Herpetologists of the Volga Region: Book of Abstracts]. Togliatti, Institut ekologii Volzhskogo basseina RAN, 1999, pp. 49-50 (in Russian).

Tabachishin V. G., Storozhilova D. A., Zavialov E. V. Amphibians of protected areas of the Saratov region. In: Problemy prirodopol'zovaniia $i$ sokhraneniia bioraznoobraziia $v$ usloviiakh opustynivaniia: tezisy dokladov mezhregional'noi nauchno-prakticheskoi konferentsii [Problems of Nature Management and Conservation of Biodiversity in Desertification Conditions: Abstracts Interregion. Scientific-Practical Conference]. Volgograd, Vseros. NII agrolesomelioratsii Publ., 2000, pp. 120-121 (in Russian).

Terentyev P. V., Chernov S. A. Opredelitel zemnovodnykh i presmykayushchikhsya [The Determinant of Amphibians and Reptiles]. Moscow, Leningrad, Sovetskaya nauka Publ., 1949. 340 p. (in Russian).

Uchebno-kraevedcheskii atlas Saratovskoi oblasti. Otv. red. V. Z. Makarov [V. Z. Makarov, ed. Educational and Local History atlas of the Saratov Region]. Saratov, Izdatel'stvo Saratovskogo universiteta, 2013. 143 p. (in Russian).

Chernov S. A. Reptiles (Reptilia) and Amphibians (Amphibia). In: Zhivotnyi mir SSSR [The Animal World of the USSR]. Moscow, Leninigrad, Izdatel'stvo AN SSSR, 1937, vol. 1, pp. 326-345 (in Russian).

Chernov S. A. Reptiles and Amphibians. In: Uspekhi biologicheskikh nauk v SSSR za dvadtsat' let [Advances in biological sciences in the USSR for twenty years]. Moscow, Leningrad, Izdatel'stvo AN SSSR, 1945, pp. 115-118 (in Russian).

Shlyakhtin G. V. On some seasonal changes in the nervous tissue of the digestive tract of poikilothermic animals. In: Fiziologicheskaia $i$ populiatsionnaia ekologiia zhivotnykh [Physiological and Population Ecology of Animals]. Saratov, Izdatel'stvo Saratovskogo universiteta, 1980, iss. 6, pp. 126-131 (in Russian).

Shlyakhtin G. V. The trophic niches of cohabiting species anuran amphibian. Russian J. of Ecology, 1985 a, no. 6, pp. 24-32 (in Russian). 
Shlyakhtin G. V. Phenetic analysis of the color of the back of a marsh frog. Fenetika populiatsii: materialy III Vsesoiuznogo soveshchaniia [Phenetics of Populations: Materials of the III All-Union. Conference]. Moscow, Institut biologii razvitiia im. N. K. Kol'tsova Publ., 1985 b, pp. 173-174 (in Russian).

Shlyakhtin G. V. Ekologiia pitaniia $i$ adaptivnye osobennosti pishchevaritel'nogo trakta zimospiashchikh pozvonochnykh [Feeding Ecology and Adaptive Features of the Digestive Tract of Hibernating Vertebrates]. Thesis Diss. Dr. Sci. (Biol.). Saratov, 1987. 24 p. (in Russian).

Shlyakhtin G. V., Golikova V. L. Metodika polevykh issledovanii ekologii amfibii i reptilii [Methodology of Field Studies of the Ecology of Amphibians and Reptiles]. Saratov, Izdatel'stvo Saratovskogo universiteta, 1986. 78 p. (in Russian).

Shlyakhtin G. V., Zavialov E. V. Dynamics of the trophic spectrum of the marsh frog Rana ridibunda by the example of various variants of water-land ecotone systems. In: Problemy izucheniia kraevykh struktur biotsenozov: tezisy dokladov Vserossiiskogo seminara [Problems of Studying the Edge Structures of Biocenoses: Abstract of the All-Russian Workshop]. Saratov, Izdatel'stvo Saratovskogo universiteta, 1997, pp. 27 (in Russian).

Shlyakhtin G. V., Belyachenko A.V., Kashirskaya E. V., Zavialov E. V. Genesis and spatial-temporal structure of ecotones of the upper zone of the Volgograd reservoir. In: Biologiia, ekologiia, biotekhnologiia i pochvovedenie [Biology, Ecology, Biotechnology and Soil Science]. Moscow, Izdatel'stvo Moskovskogo universiteta, 1994, pp. 76-91 (in Russian).

Shlyakhtin G. V., Zavialov E. V., Anikin V. V., Malinina $\mathrm{Yu}$. A. Clutches and larvae of amphibians in bioindication of toxic substances. Tezisy VII sezda gidrobiologicheskogo obshchestva RAN [Abstracts VII Congress of Hydrobiology Society of Russian Academy of Sciences]. Kazan, Poligraf Kazan Publ., 1996, vol. 3, pp. 100-102 (in Russian).

Shlyakhtin G. V., Zavialov E. V., Yakushev N. N., Tabachishin V. G., Storozhilova D. A., Banadyk O. V. 2001. Seasonal Feeding Dynamics of the European Firebellied Toad Bombina bombina (Discoglossidae, Anura, Amphibia) in the Conditions of the Saratov Region. Voprosy biologii, ekologii, khimii $i$ metodiki obucheniia [Questions of biology, ecology, chemistry and teaching methods]. Saratov, Sigma-plius Publ., $2001 a$, iss. 4, pp. 48-50 (in Russian).

Shlyakhtin G. V., Zavialov E. V., Shlyakhtina Yu. V., Tabachishin V. G. The Functional Significance of the Marsh Frog in the Ecosystems of the Volgograd Reservoir. In: Fundamental and Applied Aspects of Aqueous Ecosystems Functioning: Problems and Perspectives of Hydrobiology and Ichtyology in XXI centurt: Proceedings All Russian Scientific Conference. Saratov, Izdatel'stvo Saratovskogo universiteta, 2001 b, pp. 199-202 (in Russian).

Shliakhtin G. V., Beliachenko A. V., Mosolova E. Yu., Tabachishin V. G. Biological structure and dynamics of the aquatic-ground ecotones of the upper zone of the Volgograd reservoir. Povolzhskiy J. of Ecology, 2014, no. 1, pp. 74-81 (in Russian).

Shcherbak N. N., Tokar A. A., Kirilenko I. V. Catalogue of Collections of the Zoological Museum NMNH, NAS of Ukraine. The Common Geckos (Reptilia: Sauria, Geckonidae). Kiev, Zoomuseum NMNH NAS of Ukraine Publ., 2003. 46 p. (in Russian).

Boettger O. Katalog der Reptilien-Sammlung im Museum der Senckenbergisch en Naturforschenden Gesellschaft im Frankfurt am Main. Frankfurt am Main, 1898, Bd. 2, teil 2. $160 \mathrm{~S}$.

Boulenger G. A. Catalogue of snakes in the British Museum (Natural History). Vol. I. Containing the families Typhlopidae, Glauconiidae, Boidae, Ilysiidae, Uropeltidae, Xenopeltidae, and Colubridae Aglyphae. London, Trustees of the British Museum, 1893. 448 p.

Boulenger G. A. Catalogue of snakes in the British Museum (Natural History). London, 1894, vol. 2. 382 p.

Boulenger G. A. Catalogue of snakes in the British Museum (Natural History). Vol. 3. Containing the Colubridae (Opisthoglyphae and Proteroglyphe), Amblycephalidae and Viperidae. London, Trustees of the British Museum, 1896. 727 p.

Cope E. D. Catalogue of the Colubridae in the Museum of the Academy of Natural Sciences of Philadelphia, with notes and description of new species. Part 2. Proceedings Academy of Natural Sciences of Philadelphia, 1860, no. 12, pp. 241-266.

Fischer G. Museum Historiae Naturalis Universitatis Caesareae Mosquensis. I: Animalia. Mosquae, Typis Universitatis Caesareae, 1822. 76 p.

Gunther A. C. Catalogue of the colubrinae snakes in the collection of the British Museum. London, British Museum (Natural History), 1858. 282 p.

Muller F. Katalog der im Museum und Universitatskabinet zu Basel aufge stellten Amphibien und Reptilien nebst Anmerkungen. Basel, 1878, vol. 6, pp. 551-709.

[Pallas P. S.] P. S. Pallas D. A. D. Professors der Natur-Geschichte und ordentlichen Mitgliedes der Russisch-Kayserlichen Academie d. W. der freyen oeconomischen Gesellschaft in St. Petersburg, wie auch der Römisch-Kayserlichen Academie der Naturforscher und Königl. Engl. Societät; Reise durch verschiedene Provinzen des Russischen Reichs. Erster Teil. SPb., Kayserliche Academie der Wissenschaften, 1771. 504 S.

[Pallas P. S.] P. S. Pallas D. A. D. Professors der Natur-Geschichte und ordentlichen Mitgliedes der Russisch-Kayserlichen Academie d. W. der freyen oeconomischen Gesellschaft in St. Petersburg, wie auch der Römisch-Kayserlichen Academie der Naturforscher und Königl. Engl. Societät; Reise durch verschiedene Provinzen des Russischen Reichs. Dritter Teil. SPb., Kayserliche Academie der Wissenschaften, 1776. $760 \mathrm{~S}$.

Pallas P. S. Zoographia Rosso-Asiatica, sistens omniun animalium in extenso Imperio Rossico et adjacentibus maribus observatorum recensionem, domicilia, mores et descriptions, anatomen atque icones plurimorum; auctore 
Э. И. Кайбелева, М. В. Ермохин, Е. Н. Кондратьев и др.

Petro Pallas, eq. Aur. Academico Petropoliano. Tomus III. Animalia monocardia seu frigidi sanguinis Imperii Rosso-
Asiatici. Petropoli, ex officina Caes. Academiae Scientarum, $1814.428 \mathrm{p}$.

\section{Cite this article as:}

Kaybeleva E. I., Yermokhin M. V., Kondratiev E. N., Mosolova E. Yu., Tabachishin V. G., Shlyakhtin G. V. Amphibian Scientific Collection of the Zoological Museum of Saratov State University as the Basis for the Regional Cadastre. Current Studies in Herpetology, 2019, vol. 19, iss. 3-4, pp. 95-124 (in Russian). DOI: https://doi.org/10.18500/18146090-2019-19-3-4-95-124 